\title{
Tasavvufta Tevekkül Anlayışı
}

\author{
Dr. Öğr. Üyesi Mansur GÖKCAN*
}

Atıf / @ - Gökcan, M. (2018). Tasavvufta Tevekkül Anlayışı, Çukurova Üniversitesi Ilahiyat Fakültesi Dergisi, 18 (1), 131-165.

Öz- Dinî naslarda, her mü'minin mükellef olduğu bir fariza olarak yer alan tevekkül, tasavvufta da önemli bir makam olarak yer almaktadır. Bir işte acziyet gösterip işi başkasına havale etmek anlamını taşıyan tevekkülde, Allah'a güven ve teslimiyet esastır. Güvenmek ve itimat etmek, tanımakla ilgilidir. Bir kimsenin marifeti arttıkça güveni de artar. Allah'a en çok güvenen kimse, O’nu en çok tanıyan kimsedir. Peygamberlerin, Allah'a en çok güvenen kimseler olmaları, Allah'ı en iyi tanıyan kimseler olmalarındandır. Bu durum, tevekkülün derecesinin, marifetin derecesine bağlı olduğunu da göstermektedir. Eşyanın varlığı kendisinden olmadığı gibi, sahip olduğu güç de kendisinden değildir. "Işığın ve hararetin sebebinin güneş" olduğunu zannetmek gaflettir. Bütün varlıklar Allah'la mevcuttur ve O'nun verdiği güçle varlığını sürdürmektedir. Bu hakikate yakîn olarak ulaşan kimse, Allah'tan başkasında güç ve kuvvet olmadığını idrak ederek yaratılana değil yaratıcıya güvenir. Sadece O’ndan yardım diler ve O'na teveccüh eder. Allah'ın, bütün mahlûkatın rızkına kefil olduğu bilgisiyle rızık kaygısı çekmeyerek huzur ve sükûn içerisinde yaşar. Allah'a inanmanın gereği olan tevekkül, başa gelenlere karşı sabır ve rıza göstermeyi, aza kanaat etmeyi, mutlak bir güveni ve teslimiyeti öngörür. Tevekkül, sağlam bir havf ve recâ anlayışına sahip olmayı da gerektirir. Allah'tan korkan kimse, başkasından korkmaz. Allah da, kendisinden korkan ve ümitvâr olan kimseyi başkasının eline bırakmaz. lyi görünen şeylerin sonu kötü, kötü görünen şeylerin sonu da iyi olabilir. İşlerin iç yüzünün ve akıbetinin bilgisi sadece Allah'a ait olduğu için, Allah'a güvenmek, işleri O'na havale etmek ve takdirine rıza göstermek gerekir. Kalbin işi olan tevekkül, bedenen çalışmaya engel değildir. Tevekkül, hiçbir şey yapmadan sadece kalben güvenip beklemeyi değil, aynı zamanda bedenen gereken gayret ve çabayı sarf etmeyi de icap ettirir. Tevekkül, rızk kaygısı çekmeyerek huzurlu bir hayat yaşamanın, başkasına muhtaç olamayarak izzet ve şerefi korumanın yoludur.

Anahtar sözcükler- Tevekkül, kalp, iman, güven

Makalenin gelişi: 25.04.2018; Yayına kabul tarihi: 12.06.2018

* Çukurova Ü. İlahiyat Fakültesi Tasavvuf Anabilim Dalı, eposta: mgokcan37@hotmail.com (ORCID: 0000-0001-9366-7266) 


\section{$\S \S \S$}

\section{Giriş}

Tasavvufta önemli bir makam olan tevekkül, Kur'an'da, her mü'minin riayet etmesi gereken bir fariza olarak yer almaktadır. ${ }^{1}$ Iman, kalbî bir tasdikle inanmayı, tevekkül de, inandığı kimseye güvenmeyi gerektirir. Tevekkülün esasında Allah'a güven ve teslimiyet vardır. Allah, yarattığı varlıkları kendi hallerine bırakmayarak rızklarını takdir etmiş ve dünyayı da tüm mahlûkatın yaşayabileceği, rızkını temin edebileceği bir mekân olarak tanzim etmiştir. Allah, her canlının rızkının kendisine ait olduğunu² bildirerek sadece kendisine güvenilmesini ve başkasından rızk talep edilmemesini istemiştir. $O$ halde Rezzâk olan Allah'a tevekkül ederek tamamen O'na teslim olmak gerekir. Namazın her rekâtında okunan Fatiha'da, "Yalnız sana ibadet eder ve yalnız senden yardım bekleriz."3 denilerek, Allah'tan başkasından bir şey beklenmeyeceği sözü verilmektedir. Kuşeyrî (ö. 465/1072), verilen bu söze riayet etmeyerek tersini yapmanın şirke götüreceğini şu sözlerle ifade etmiştir: "Şirk, sadece putlara tapmak değildir. Şirk, Allah'ın dışında, dünyadaki veya ahiretteki bir şeyi tercih etmendir. Allah'tan başkasına dayandığın zaman O'na şirk koşmuş olursun. Allah'tan sakın ve başkasına dayanma. Allah'tan kork ve başkasına güvenme."4

Kuşeyrî̀nin ifadelerinden anlaşılacağı üzere, Allah'tan başkasında güç ve kuvvet olduğunu kabul ederek onlara teveccüh etmek, Hakk'a değil de halka güvenmek, Hak'tan değil de halktan korkmak ve onlara ümit bağlamak şirktir. Böyle bir davranış; imanda, teveccühte, tevekkülde, havf ve recâda problem olduğunu gösteren bir anlayışın eseridir.

Fatiha sûresinde, Allah'ın "Melik" olduğu, ${ }^{5}$ yani her şeyin yegâne sahibi olduğu ifade edilmektedir. Eğer bu ifade, dildeki söylemden ibaret olarak kalır da kalbe inip yerleşmezse iman açısından bir anlam ifade etmez. İman, sadece dildeki ifade değil, aynı zamanda kalbin tasdikidir. Imam Maturidî (ö. 333/944), imanı "dil ile ikrar ve kalp ile tasdik" olarak ifade ederken; imanda, kalbin tasdikinin esas olduğunu, dil ile ikrarın ise, kişinin toplum içerisinde

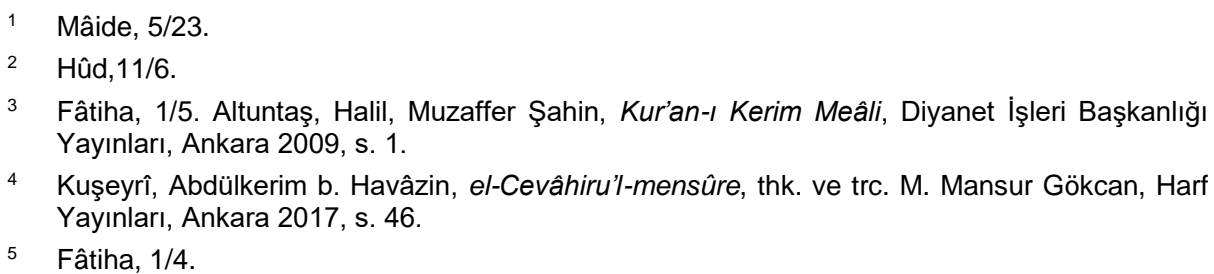


Müslüman muamelesi görmesi için gerekli olduğunu belirtmiştir. Dinden dönmesi için zorlanan kişinin (mukreh'in), kalbî olmayan ifadesiyle dinden çıkmayacağı da bu konuya örnek olarak verilmiştir. ${ }^{6}$

Gazâlî (ö. 505/1111), tevekkülün büyük bir makam olduğunu, Allah'ın, bu makamdaki kulunu sevdiğini, koruduğunu ve gözettiğini söylemiştir. Allah'ın sevdiği bir kimseyi kendisinden uzaklaştırmayacağını, mahcup etmeyeceğini ve ona azap etmeyeceğini açıklamıştır. Gazâlî, ateşe atılan Hz. İbrahim'in, Cibrîl'in yardım teklifini, "Sana intiyacım yok. Allah bana yeter. O, ne güzel vekildir." diyerek reddettiğini ve Allah'a tevekkül ettiğini bildirmiştir. ${ }^{7}$ Bilindiği gibi, neticede Allah Teâlâ da, kendisini kâfî görerek tevekkül eden Peygamberini mahcup etmemiş ve ateşe serinlik verme özelliği yükleyerek onu selamete kavuşturmuştur. ${ }^{8}$ Bu vakıadan da anlaşılacağı üzere, Allah'a tevekkül edenlerin akıbeti ateşte yanmamak, O'na tevekkül etmeyenlerin akıbeti ise kıvılcımla dahi tutuşmaktır.

Bu makalede; tevekkülün tanımı, mahiyeti, elde etme yolları, mertebeleri, zamanı, kazanımları ve tevekkül-vahdet ilişkisi işlenecektir. Konunun işlenmesinde, tasavvufun klasik kaynakları esas alınacak ve mümkün olduğu kadar da diğer eserlere yer verilecektir. Bir makale boyutunu aştığı için "Tevekkülün Yanlış Algılanması" da ayrı bir makalede işlenecektir.

\section{Tevekkül Kavramı ve Tanımları}

Tevekkül, işi başkasının yapmasını kabullenmek (işi başkasına havale etmek), bir işte acziyet gösterip başkasına güvenmek ve Allah'a teslim olmak $^{9}$ anlamlarına gelmektedir. Vekil kelimesi ise, "Rab, kâfi (yeterli) ve koruyucu" anlamlarına gelmektedir. Vekil, Allah'ın sıfatlarındandır. Vekil olan Allah, yarattıklarının idaresini üstlenen ve rızkına kefil olandır. Mütevekkil ise, rızkı ve işleri konusunda Allah'ı yeterli gören ve O'ndan başkasına güvenmeyen kimsedir. ${ }^{10}$

Aydın, Mehmet, İslâm Dini İlmihali, Hibaş Yayınları, Konya 1981, s. 55, 56.

Gazâlî, Ebû Hâmid Muhammed b. Muhammed, Ihyâu ulûmi'd-dîn, I-V, Müessesetü'l-Halebî, Kahire 1387/1967, IV, s. 302, 304.

8 Enbiyâ, 21/69.

9 Ahmed el-Âyid ve diğerleri, el-Mu'cemü'l-Arabiyyü'l-Esâsî, Mektebetü Lârûs, Alesco 1988, s. 1330; Halil el-Curra, Lârûs, Mektebetü Lârûs, Paris 1973, s. 356; Râgıb el-İsfahânî, Ebu'lKâsım Hüseyn b. Muhammed, el-Müfredât, Dâru'l-kalem, Beyrut 1412/1991, s. 265.

10 İbn Manzûr, Ebû'l-Fadl Cemâluddin Muhammed b. Mükrim b. Ali el-Ensârî, Lisanu'l-Arab, IVI, Dâru'I-maârif, Kahire 1979, VI, s. 4909, 4910, 4911. 
Tasavvuf kaynaklarında tevekkül, önemli bir makam olarak yer almaktadır. Mekkî (ö. 386/996), tevekkülün, yakîn makamlarının en üstünü ve velilerin hallerinin en faziletlisi olduğunu söylemiştir. Sehl b. Abdullah (ö. 283/896), makamlar içerisinde tevekkülden daha üstün bir makam olmadığını belirtmiştir. ${ }^{11}$ Gazâli'ye göre de tevekkül; din mertebelerinden bir mertebe ve yakîn sahibi kimselerin makamlarından bir makam ve mukarrabînin yüksek derecelerindendir. ${ }^{12}$ Burada Gazâli'nin, Mekkî ile neredeyse aynı ifadeleri kullandığı görülmektedir. Mekkî̀nin, tevekkülü, hem makam hem de hal olarak ifade etmesi ise, bu konuda bir farklılıktır.

Herevî (ö. 481/1089), tevekkülü, işi tamamıyla sahibine havale etmek ve O'nun vekâletine güvenmek olarak tanımlamış ve tevekkülün avama göre mertebelerin en zoru, havâsa göre ise en kolayı olduğunu söylemiştir. Herevî, Allah'ın, işlerin tamamını kendi üzerine aldığını ve âlemi bu konuda ümitsizliğe düşürdüğünü belirtmiştir. Tilimsânî’ye (ö. 690/1291) göre, tevekkülün avâma zor gelmesinin sebepleri; nefsin istediği şeyleri sevmeleri, sebepleri terk ederek gerçek müsebbibe güvenmemeleri ve gerçekte, işlerin tamamının Allah'a ait olduğunu bilmemeleridir. Tevekkülün, havâsa kolay gelmesinin sebepleri ise; işlerin tamamının Allah'a ait olduğunu ve O'nun mülkünde başkasının yapacağı bir şey olmadığını bilmeleridir. ${ }^{13}$ Mülk Allah'ındır. Mülk üzerindeki tasarruf da sadece O'na aittir. Avama tevekkülün zor, havâsa ise kolay gelmesi marifetle ilgilidir. Avam, sebepleri etken görürken havâs, müsebbibi etken görmektedir. Avam, gücü mahlûkta görürken havâs, gücü Hâlık'ta görmektedir. Herevî'nin ifadeleri ve Tilimsânî'nin açıklamaları, tevekkülün itikadî yönüne de açıklık getirmektedir. Tevekkülün esasında, halka değil Hakk'a güven vardır. Hakk’a güven de, imanın gereğidir.

Tevekkülü tanımlayan sûfîlerden birçoğu, tevekkülün kalben Allah'a güvenmek olduğu hususunda ittifak etmişlerdir. Cüneyd Bağdâdî (ö. 297/909), "Tevekkül, kalbin Allah'a güvenmesidir."14 derken, Sehl b. Abdullah da "Tevekkül, başkasına bağlanmaksızın Allah ile yaşayan kalbin halidir." 15 demiştir. İbrahim b. Havvâs da (ö. 291/904), "Tevekkül; kalbin, mala, sebebe ve mahlûka dayanmamasıdır. Tevekkül, kalbin Allah'a dayanması ve gaypta

11 Mekkî, Ebû Talib, Kûtu'l-kulûb, I-II, Dâru sâdır, Kahire 1310/1892, II, s. 2.

12 Gazâlî, İhyâ, IV, s. 2.

13 Tilimsânî, Afîfüddin Süleyman b. Ali, Şerh'u menâzili's-sâirîn, I-II, Dâru't-Türkî, Tunus 1989, I, s. $197,198$.

14 Serrâc, Ebû Nasr Abdullah b. Ali et-Tûsî, el-Lûma, Dâru'l-kütübi'l-ilmiyye, Beyrut 2001, s. 50.

15 Kuşeyrî, Ebû'l-Kâsım Abdülkerim b. Havâzin b. Neysâbûrî, er-Risâletü'l-Kuşeyrîyye, Dâru'lhayr, Beyrut 1997, s. 166. 
kendisi için ayrılan kısmet ile sükûn bulmasıdır."16 demiştir. Yapılan tanımlarda, üç mutasavvıfın ifadesinin de örtüştüğü görülmektedir. Tanımlarda, tevekkülün kalbî bir iş olduğu ve halka değil Hakk'a güvenmek gerektiği vurgulanmaktadır.

Benzer vurguları, İbn Arabî'nin (ö. 638/1240) açıklamalarında da görmek mümkündür. İbn Arabî, tevekkülün, bâtınî bir iş olduğunu, "Allah'a güvenmek" anlamına geldiğini söylemiş ve bir kimsenin, biriktirdiği mala güvenmesinin ise, tevekküle zıt olduğunu belirtmiştir. ${ }^{17}$ İbn Arabî'nin yaptığı bu tanımlamada, tevekkülün bâtınî bir iş olması; tevekkülün görünen bir iş olmayıp kalbin işi olduğu şekliyle anlaşılabileceği gibi, avamın bilmediği ve dillendirilmeyen derûnî bir yönünün olduğu şeklinde de anlaşılabilir. Tanımda, biriktirdiği mala güvenmenin tevekkül anlayışına tezat teşkil ettiğinin vurgulanması; tevekkülde, Allah'tan başka bir şeye güvenmeye yer olmadığını ortaya koymaktadır.

Ruveym'in (ö. 303/915), "Tevekkül, Allah'ın vadine güvenmektir."18 şeklindeki tanımında vadeliden şey rızktır. Mütevekkil, rızk konusunda endişe duymayan ve Allah'ın vadine güvenen kimsedir. Kuşeyrî, tevekkülün, Allah'ın elindekine güvenmek ve halkın elinde bulunandan ümit kesmek olarak da ifade edildiğini söylemiştir. ${ }^{19}$ Sehl b. Abdullah, "Tevekkül, yüzünü tamimiyle Allah'a çevirmen ve O'na arkanı dönmemendir."20 demiştir. Ruveym, Kuşeyrî ve Sehl'in ifadelerinde, tevekkülün, halka değil, sadece Hakk'a güvenmeyi ve teveccüh etmeyi gerektirdiği üzerinde durulmaktadır.

İbrahim b. Havvâs'ın, "Verilmesi garanti edilen şeyi elde etmek için zorlanma ve senden istenen şeyleri de zayi etme." sözü; rızk meşguliyeti ve kaygısının ilahî buyrukları yerine getirmeyi aksatacağı endişesi taşımaktadır. Onun, rüyasında, Allah'tan uzak kalma endişesiyle, Hızır'ın (a.s.) arkadaşlık teklifini reddetmesi de bu düşünceyi teyit etmektedir. ${ }^{21}$ Benzer gerekçelerle, Ebû Osman'ın (ö. 298/910), “Tevekkül, dünyaya karşı sabır göstermek ve

16 Sülemî, Ebû Abdurrahman Muhammed b. Hüseyin, el-Mukaddime fi't tasavvuf, Dâru'l-Cîl, Beyrut 1419/1999, s. 39.

17 İbn Arabî, Muhyiddîn, el-Futuhâtu'l-Mekkiyye, Dâru'l-kütübi'l-ilmiyye, I-X, Beyrut 1460/1999, III, s. 299.

18 Serrâc, age., s. 49.

19 Kuşeyrî, er-Risâletü'l-Kuşeyrîyye, s. 169.

20 Serrâc, age., s. 50.

21 Hucvirî, Ali b. Osman Cüllâbî, Keşfu'l-mahcûb, trc. İs'âd Abdülhâdî Gandil, Dâru'n-nehdetü'lğarbiyye, Beyrut 1980, s. 365; Hucvirî, Keşfu'l-mahcûb, çev. Süleyman Uludağ, Dergâh Yayınları, İstanbul 1996, s. 257. 
kalbin onunla ilişkisini kesmektir."22 dediği görülmektedir. Dünyaya karşı sabır göstermek, dünyadaki hazlara karşı sabır göstermek ve dünyadaki nimetlerin cazibesine kapılarak dünyaya bağlanmamaktır. Dünya, yaşanılan ve istifade edilen bir mekândır. İhtiyaçların karşılanması için dünya metaından faydalanmak zarureti vardır. Fakat önemli olan, dünya metaını kalbe sokmamaktadır. Dünya metaının kalbe girerek onu meşgul etmesi, kalbin, Allah'la ve ahiret hazırlıklarıyla ilgilenmesine zaman bırakmamaktadır. Kalbi, dünyanın ve nefsin elinden kurtarmanın yolu tevekküldür. Tevekkül, kalbin dünya ile ilişkisini keserek onu Allah'a bağlayan önemli bir prensiptir.

Muhâsibî (ö. 243/857), birtakım kimselerin, rızada ve tevekkülde ihlasla davranma azimleriyle kendilerini aldattıklarını, fakat iş amele yani ihlasla tevekkül etmeye ve rıza göstermeye gelince gaflete düşerek tevekkül etmediklerini ve rıza göstermediklerini, bunun da riya olduğunu belirtmiştir. ${ }^{23}$ Muhâsibî'nin açıklamalarında tevekkülün, sözde değil eylemde mevcut olmasının esas olduğu anlaşılmaktadır. Sadece ihlasla tevekkül etmeye azmetmek, fakat iş anında bu azmin gereğini uygulamamak tevekkül değil, tevekkülle kendi kendisini aldatmaktır. Tevekkül, kâl değil, yaşanan bir haldir.

\section{Tevekkül ve Tefvîz}

Tefvîz, tevekkül yerine kullanılan bir terimdir. Tefvîz kelimesi, işi birine havale etmek, işi teslim etmek, vekâlet vermek, ${ }^{24}$ bir kimseyi işin tasarrufunda yetkili kılmak, kendisi bulunmadığı zaman kendisi adına işleri yürütmek üzere bir kimseyi vekil kılmak ${ }^{25}$ anlamlarına gelmektedir. Tevekkül yerine de kullanıIan tefviz, işleri Allah'a havale etmek, O'nun yaptığı her işi hoş görmek ve O'na ne kalben ne de dille itiraz etmemektir. Tefvîz, tevekkülün en mükemmel şekli olarak da görülmüştür. ${ }^{26}$ Tefviz kelimesi, "Ben işimi Allah'a havale ediyorum. Şüphesiz Allah, kullarını hakkıyla görendir."27 ayetinde görüleceği üzere, “işi Allah'a havale etmek" anlamında kullanılmıştır.

Gazâlî, bir hususta isabetli karar vermek için, o işin içini-dışını, başınısonunu iyi bilmek gerektiğini; gerçek altını sahtesinden bir çobanın değil, ancak sarrafın ayırt edebileceğini söylemiş; bu sebeple işleri, bütün işlerin içyü-

22 Sülemî, age., s. 39.

23 Muhâsibî, Ebû Abdullah Hâris b. Esed, er-Riaye li-hukûkillah, Dâru'l-kütübi'l-ilmiyye, Beyrut 2010, s. 471.

24 İbn Manzûr, age., V, s. 3485.

25 Ahmed el-Âyid ve diğerleri, age., s. 955.

26 Uludağ, Süleyman, Tasavvuf Terimleri Sözlüğü, Marifet yayınları, İstanbul 1991, s. 477.

27 Mü'min, 40/44. 
zünü bilen ve kul için en doğru kararı verecek olan Allah'a bırakmak gerektiğini belirtmiştir. Gazâlî, işleri, gökleri ve yeryüzünü idare eden Allah'a havale etmek (tefvîz), en bilgin ve en merhametli olan Allah'ın kararına rıza göstermek ve sadece akıbeti ilgilendiren işlerle ilgilenmek gerektiğini açıklamıştır. ${ }^{28}$ Burada, işleri Allah'a havale etmek anlamında olan tefvîzin tevekkül yerine kullanıldığı görülmektedir. İnsanoğlu, bâtınî bilgiden yoksun olduğu için genellikle zâhire göre hareket eder. Fakat zâhir insanı aldatabilir. İyi görünen şeylerin sonu kötü, kötü görünen şeylerin sonu da iyi olabilir. İşlerin iç yüzünün ve akıbetinin bilgisi sadece Allah'a ait olduğu için, Allah'a güvenmek, işleri O'na havale etmek ve takdirine rıza göstermek gerekir.

Herevî, tefvîzin, tevekkülden daha geniş bir anlam ifade ettiğini, "Tevekkül, sebebin (olayın) vukuundan sonradır. Tefvîz ise, olayın hem vukuundan önce hem de vukuundan sonradır. Tefvîz, teslim olmanın bizzat kendisidir. Tevekkül, tefvîzin bir bölümüdür."29 diyerek izah etmiştir. Buradaki açıklamalara dayanarak, tefvîzin tevekkülden farklı olan yönleri, üç madde halinde ifade edilebilir: 1. Tefvîz, tevekkülden daha geniş bir anlam ifade eder. 2. Tevekkül, tefvizin bir bölümüdür. 3 . Tefvîz, olayın vukuundan önce de söz konusudur.

İbrahim Hakkı'ya (ö. 1115/1703) göre tefvîz, dünya işlerinden herhangi bir şeyi tercih etmeyip Allah'ın tercihine teslim olmak ve itiraz etmemektir. Tefvîz, kazadan (olaydan) önce, teslim ise kazadan sonradır. Tefvîz, Hakk'a teslim olmak ve O'ndan gelene rıza göstermektir. Müfevvîz, halkı kendisi gibi aciz bilerek her işini Allah'a havale eden, her halinde Allah'a sığınan, her durumda sükûn ve huzur içerisinde olan kimsedir. Teslim olmak; musibet şerbetini inleyip ağlamadan yudumlamak; zorlukla kolaylığı, hastalıkla sağlığı bir kabul etmek ve bela geldiğinde değirmen taşının alttaki parçası gibi olmaktır. ${ }^{30}$

Herevî ve İbrahim Hakkı'nın, tefvîzin, kazadan (hükümden, olaydan) önce de söz konusu olduğu hususunda ittifak ettikleri görülmektedir. Tefvîzin (Allah'a havale edilen işin), öncesinde güven, sonrasında ise teslimiyet ve rıza olduğu anlaşılmaktadır.

28 Gazâlî, Ebû Hâmid Muhammed b. Muhammed, Minhâcü'l-âbidîn, Müessesetü'r-risâle, Beyrut 1409/1989, s. 234, 235, 236.

29 Herevî, Ebû İsmail Abdullah el-Ensârî, Menâzilü's-sâirîn, Dâru'l-kütübi'l-ilmiyye, Beyrut 1988, s. 45 .

30 Erzurumlu İbrahim Hakkı, Mârifetnâme, sadeleştiren M. Fuat Başar, Âlem Tic. ve Yayıncılık, İstanbul ts. s. 378, 379. Değirmen taşının üst parçası dönerken, alt parçası sabit kalır ve böylece aradaki buğday öğütülerek bulgur veya un haline getirilir. 
Abdülkerim el-Ceylî̀ye (ö. 832/1428) göre, tefviz ile teslim aynı anlamdadır. Fakat teslim olan kimse, işini teslim ettiği zattan kendisine gelene razı olmayabilir. Tefviz ehli ise, işini teslim ettiği zatın hükmüne boyun eğer ve O'ndan gelen her şeye de razı olur. ${ }^{31}$ Marifetnâme'de yer alan tefvîznâme isimli şiirde tevekkül ile tefvîzin aynı anlamlarda ve bir arada kullanıldığı görülmektedir. ${ }^{32}$

Hak şerleri hayr eyler, zannetme ki gayreyler

Mevlâ görelim neyler, neylerse güzel eyler.

Sen Hakk'a tevekkül kıl, tefvîz et ve rahat bul

Sabreyle ve razı ol, Mevlâ görelim neyler, neylerse güzel eyler.

Yukarıda görüldüğü gibi, Herevî, tevekkülün, olayın vukuundan sonra; tefvîzin ise hem olayın vukuundan önce hem de vukuundan sonra olduğunu belirterek tevekkül ile tefvîzi birbirinden ayırmıştır. İbrahim Hakkı, tefvîzin, olayın öncesinde olduğunu söylemiş, fakat tefvîzi tevekkülle birlikte ve aynı anlamlarda kullanmıştır. Gazâlî de tefvîzi, tevekkül ile aynı anlamda kullanmıştır. Her iki kelime de birbirinin yerine kullanılmakla birlikte tasavvuf kaynaklarında tevekkülün daha çok öne çıktığı görülmektedir.

\section{Tevekkül Sahibi olmanın Yolları}

İman: Tevekkül sahibi olabilmek için güçlü bir iman gerekir. Rızkı verecek olan, ancak "rezzâk" sıfatının sahibi olan Allah'tır. O'ndan başkasına güvenmek ve onu rezzâk olarak kabul etmek şirk kokman bir davranıştır. "Eğer mü'min iseniz sadece Allah'a tevekkül edin/güvenin."33 ayetinde, tevekkülün, imanın gereği ve neticesi olduğuna; Allah'tan başkasına güvenerek tevekkül etmemenin de, iman dairesinden çıkararak küfre götürebileceğine işaret edildiği görülmektedir.

Sülemî (ö. 412/1021), zikredilen ayette, Allah'ın tevekkülü emrettiğini, onu imanla birleştirdiğini, imanın hakikati yaptığını ve tevekkülle müritlerin kalplerini kuvvetlendirdiğini ifade etmiştir. Hz. İsa'ya, "Bana tevekkül et. Ben sana kâfiyim. Benden başkasına yönelme. Yoksa seni terk ederim. Kim Al-

31 Ceylî, Abdülkerim, İnsan-ı Kâmil, trc. Abdülkadir Akçiçek, Kurtuba yayınları, İstanbul 2016, s. 822.

32 Erzurumlu İbrahim Hakkı, age., s. 409.

33 Mâide, 5/23. 
lah'tan başkasına yönelirse sıkıntı çeker." şeklinde vahyedildiği bildirilmektedir. ${ }^{34} \mathrm{Bu}$ ifadelerden, tevekkül ile imanın, etle tırnak gibi birbirine bağlı olduğu ve birbirini tamamladığı anlaşılmaktadır. Tevekkülün doğru olması, imanın doğru ve güçlü olmasına bağlıdır. Tevekkül, kalplerin güçlenerek Allah'a bağlanmasına ve huzur bulmasına sebep olmaktadır. Tevekkülden ayrılarak başkasına teveccüh etmenin akıbeti ise sıkıntı çekmek ve huzursuz bir kalple hayat geçirmektir.

Ebû Yakup es-Sûsî de, "Kim tevekkül edeni kötülerse, imanı kötülemiş olur. Çünkü tevekkül imana bitişiktir. Kim tevekkül edeni severse, Allah'ı sevmiş olur." 35 diyerek tevekkül ile imanın birlikteliğine vurgu yapmıştır. Onun sözlerinden, mütevekkilin imanının güçlü ve Allah katındaki değerinin de yüksek olduğu anlaşılmaktadır.

İbn Arabî, tevekkülün; ilmin değil imanın, âlimlerin değil, mü'minlerin özelliği olduğunu söylemiş ve âlimlerin tevekkül sahibi olmalarının ancak inanmalarına bağlı olduğunu belirtmiştir. ${ }^{36}$ İlmin genel olarak ifade edildiği, dînî ilimler veya pozitif ilimler diye bir ayrım yapılmadığı görülmektedir. Bilmekle, inanmak farklı şeylerdir. Bildiği halde inanmayan kimseler olduğu gibi, inandığı halde amel etmeyen kimseler de vardır. Fakat bilimin imanla birlikteliğinin, imanı kuvvetlendireceği ve daha güzel amel etmeyi sağlayacağı da aşikârdır.

Lokman, oğluna yaptığı nasihatta, imanın dört esası olduğunu; vücudun iki el ve iki ayakla işlerini yürüttüğü gibi imanın da ancak bu dört esasla sahih olacağını söylemiştir: Allah'a tevekkül etmek ve hükmüne teslimiyet göstermek, İşleri O'na havale etmek ve takdirine razı olmak. ${ }^{37}$ Lokman'ın ifade ettiği iman esaslarını; "tevekkül, teslim, tefviz ve rıza" olarak da isimlendirmek de mümkündür. Tevekkül ile tefviz de aynı anlamda kullanıldığına göre, tevekkülün, imanın esaslarının yarısı olduğu da söylenebilir.

Gazâlî de, tevekkülü imanın bölümlerinden biri olarak kabul etmiş ve tevekkülün, tevhid üzerine bina edilmesi gerektiğini söylemiştir. Ona göre, kim, "Ortağı ve benzeri olmayan Allah'tan başka ilah yoktur. Mülk O'nundur. Hamd, O'na mahsustur. O'nun her şeye gücü yeter." sözünü kalpten söylerse, tevekkülün aslı olan iman onun için tamamlanmış olur. ${ }^{38}$ Gazâlî’nin ifadelerin-

\footnotetext{
34 Sülemî, el-Mukaddime fi't tasavvuf, s. 35, 37.

35 Mekkî, age., II, s. 3.

36 İbn Arabî, age. III, s. 300.

37 Mekkî, age., II, s. 5.

38 Gazâlî, İhya, IV, s. 305.
} 
den, "kelime-i tevhidi," ne anlama geldiğini bilerek kalbî bir tasdikle söyleyen kimsenin hem iman hem de tevekkül sahibi olacağı anlaşılmaktadır. Bu tespit, tevhidî bir imana sahip olmadan da tevekkül sahibi olunamayacağını ortaya koymaktadır.

Allah'ı yeterli görmek ve başkasından bir şey beklememek: Tevekkül, sadece Allah'a dayanmayı ve güvenmeyi gerektirir. Allah, tüm canlıların rızkının kendisine ait olduğunu ${ }^{39}$ bildirdiğine göre O'nun bu vadine güvenmek ve başkalarına meyletmemek icap eder. Hz. Ali'nin şu sözleri de, Allah'tan başkasına güvenmemek ve O'ndan başkasından bir şey beklememek gerektiğini ortaya koymaktadır:

Allah'ın vereceği rızkı başkasından mı istiyorsun?

Yaptığın kötülükten habersiz kendini güvende sanıyorsun,

Müşrik bile olsa sarrafın verdiği garantiye inanıyorsun,

Fakat Rabbinin verdiği garantiye inanmıyorsun! $!^{40}$

Güvenmek, tanımakla ilgilidir. İnsan, tanımadığı bir kimseye güvenmez ve ona herhangi bir konuda vekâlet de vermez. Bu bakımdan tevekkülün evveli, vekil olan Allah'ı tanımak, yani marifettir. O, izzet ve hikmet sahibidir. İzzetiyle verir ve hikmetiyle de vermez. Yani O'nun vermesi yüceliğindendir. Vermemesinde de bizim bilemeyeceğimiz bir hikmet vardır. Kul, O'nun hükmüne rıza gösterirse yücelir. Aciz ve muhtaç olan kul, Allah'ı dikkatlice müşahede ettiği zaman; O'nun, adaletle hükmettiğini, her şeyi takdir ettiğini, yerin ve göğün hazinelerinin O'nun olduğunu görür. ${ }^{41}$

Gazâlî, "Tevekkül, marifetin ve tevhidin sonucudur. Hz. Peygamber de, muvahhidlerin efendisi ve ariflerin başıdır." ${ }^{2}$ demiştir. Mekkî'nin, "Tevekkülün evveli marifettir." sözüyle Gazâlî̀nin, "Tevekkül, marifetin sonucudur." sözü, örtüşmektedir. Gazâlî, tevekkülün, tevhidin de sonucu olduğunu ilaveten belirtmiştir. Allah'ı en iyi tanıyan ve birliğine de yakînen şahit olan Hz. Peygamber, ariflerin başı ve muvahhidlerin efendisi olarak vasıflandırılmıştır. Yapılan açıklamalardan, tevekkülün derecesinin, marifetin ve tevhidin derecesiyle doğru orantılı olduğu anlaşılmaktadır.

39 Hûd, 11/16.

40 Gazâlî, Minhâcü'l-âbidîn, s. 229.

41 Mekkî, age., II, s. 3.

42 Gazâlî, Ebû Hâmid Muhammed, Mükâşefetü'l-kulûb, Mektebetü Üsame b. Zeyd, Halep ts. s. 125. 
Mütevekkil, rızık konusunda Allah'ı "kâfî" gören ve rızk endişesi çekmeyen kişidir. Mekkî’ye göre mütevekkil; kalp huzuruna kavuşmuş bir kimsedir. O, kulların elindeki şeylere tamah etmez ve onları düşünmez. Mütevekkilin kalbi, Allah'a bağlı ve fikri O'nunla meşguldür. Mütevekkil, Hakk'ı söylemekten ve onunla amel etmekten çekinmez. Halktan çekinerek Hakk'ı terk etmez. Halkın huzur bulduğu şeyle huzur bulmaz. Çünkü o, rızkın, fayda ve zararın sadece Allah'tan geldiğini yakîn olarak bilir. Mekkî, bu hususları, tevekkülün farzları olarak kabul etmiş ve bunlara riayet etmeyen kimselerin tevekkülün sınırlarının dışına çıkacağını ve yakîninin zayıflayacağını belirtmiştir. ${ }^{43}$

Tevekkül, Allah'ı, rızk konusunda kâfî görmeyi ve O'nun, rızka vekîl olduğunu bilerek başkasına teveccüh etmemeyi gerektirir. Bu durum Kur'an'da, "Kim Allah'a tevekkül ederse, Allah ona yeter."44 "Allah'a güven. Vekil olarak Allah yeter." 45 ayetleri ile ifade edilmiştir. Hz. Peygamber, "Kim sıkıntıya düşer de halini insanlara açarsa sıkıntıdan kurtulamaz. Fakat düştüğü sıkıntıyı Allah'a havale eden kimseye Allah, er veya geç bir rızk verir."46 diyerek, Hakk'ın kâfî olduğunu, halka değil de Hakk'a güvenmek ve teveccüh etmek gerektiğini ifade etmiştir.

Havf ve Recâ: Tevekkül, Allah'tan başkasından bir şey beklememeyi ve korkmamayı da gerektirir. Mütevekkilin havfı da racâsı da Allah'tandır. Allah Teâlâ'nın, "Eğer Âdemoğlu, benden korkarsa, onu başkasından korkutmam. Eğer benden ümitvâr olursa, onu başkasının eline bırakmam." dediği nakledilmiştir. Yaratılanlardan korkmanın, yaratıcı korkusunun eksikliğinin cezası olduğu söylenmiştir. Fudayl b. Iyaz da (ö. 187/803), "Kim Allah'tan korkarsa, her şey ondan korkar.” demiştir. ${ }^{47}$ Tevekkül sahibi olmak için, sağlam bir havf ve recâ anlayışına sahip olmak gerektiği de anlaşılmaktadır. Allah'tan korkan kimsenin, başkasından korkmayacağı ve O'ndan ümitvar olan kimsenin, başkasının eline bırakılmayacağı vadi, tevekkül ehli için güzel bir müjdedir.

Zühd: Tevekkülün sebeplerinden birisi de zühddür. Dünya metaına değer veren ve ona bağlı olan kimsenin tevekkül sahibi olması mümkün değildir. Çünkü dünya metaına, yani halka teveccüh eden kimse Hak'tan uzaklaşır.

\footnotetext{
43 Mekkî, age., II, s. 5.

44 Talâk, 65/3.

45 Ahzâb, 33/3.

46 Tirmizî, Ebû Îsâ Muhammed b. Îsâ b. Sûre, Sünenu't-Tirmizî, I-V, Beyrût ts. Zühd, 18; Ebû Dâvûd, Süleyman b. el-Eş'as es-Sicistânî, Sünenu Ebî Dâvûd, I-III, Beyrût 1409/1988, Zekât, 28.

47 Mekkî, age., II, s. 4.
} 
Tevekkülün esasında, dünya metaına kalpte değer vermeyen bir zühd anlayışı vardır. Mekkî, "Uzun yaşama isteği, eğlenmek ve dünyadan zevk almak için olursa, bu zühd için de tevekkül için de noksanlıktır." diyerek zühdün, tevekkül ile ilişkisine ve tevekkülü elde etmedeki rolüne değinmiştir. Mekkî’ye göre, zühd, tevekkülün özel şartlarındandır. Fakat tevekkül, zühdün genel şartlarından bile değildir. Bu bakımdan, makam sahibi her mütevekkil zâhittir. Fakat her zâhid mütevekkil değildir. Çünkü tevekkül, bir makam, zühd ise bir haldir. ${ }^{48} \mathrm{Bu}$ durumda, zühdün, tevekkül makamında bulunan kimsenin hali olduğu anlaşılmaktadır. Bir kimsenin halinin ve davranışının zühde uygun olmaması, o kimsenin tevekkül sahibi olmadığının alametidir.

Hz. Peygamber'in, "Dünyada zühd, Allah'ın elindekine kendi elindekinden daha çok güvenmendir." 49 sözünde görüldüğü gibi, zühdün içerisinde de Allah'a güvenmek anlamı bulunmaktadır. Bu durum, Hakk'a değil de, halka güvenen ve onların elindeki şeylere değer veren kimsenin, ne zühd ne de tevekkül sahibi olamayacağını göstermektedir.

Teslimiyet ve rıza: Tevekkül sahibi olmanın yollarından biri de teslimiyet ve rızadır. Tevekkül, kadere rızayı ve Allah'ın hükmüne (kazaya) teslimiyet göstermeyi gerektirir. Lokman (a.s.), “Kim, Allah'a tevekkül eder, hükmüne/kazasına teslimiyet gösterir, işleri O'na havale eder ve kaderine razı olursa dini ayakta tutmuş olur." demiştir. Ebu'd-Derdâ (ö. 32/652), İmanın zirvesinin ihlas olduğunu ve tevekkülün, Allah'a teslimiyeti gerektirdiğini ifade etmiştir. ${ }^{50}$ Sehl b. Abdullah da, Tevekkülün, kişinin kendisini murad-ı ilahiye teslim etmesi olduğunu belirtmiştir. ${ }^{51}$ Tevekkül konusunda açıklamalar yapan üç kişinin de, tevekkülün, Allah'ın "hükmüne teslimiyet" gerektirdiği hususunda ittifak ettikleri, fakat Lokman'ın (a.s.), bu tespite bir de "kadere rızayı" eklediği görülmektedir.

Hasan Basrî (ö. 110/728), “Tevekkül, Allah'ın takdirine rıza göstermek demektir. Allah, mahlûkatı yaratmadan önce rızklarını yarattı. Allah, yarının amelini kendisinden istemediği gibi, mütevekkil de yarının rızkını Allah'tan istememelidir." 52 demiştir. Rızkın yaratılması, ezelde herkesin rızkının takdir edilmesi olarak düşünülebileceği gibi; dünyanın, rızk temin edilebilecek bir

\footnotetext{
48 Mekkî, age., s. 20.

49 İbn Mâce, Sünenü İbn Mâce, I-V, Dâru'r-risâletü'l-âlemiyye, Beyrut 1430/2009, Zühd, 1; Tirmizi, Zühd, 29.

50 Mekkî, age., II, s. 2, 3.

51 Serrâc, el-Lüma, 50; Kelâbâzî, Ebû Bekr Muhammed b. İshâk, et-Tarruf li-mezhebi ehli'ttasavvuf, thk. Ahmed Şemsüddin, Dâru'l-kütübi'l-ilmiyye, Beyrut 2011, s. 119.

52 Mekkî, age., II, s. 8.
} 
ortam haline getirilmesi şeklinde de düşünülebilir. Mahlûkat, yaratılıp kendi haline bırakılmamış, rızıkları kendilerinden önce yaratılarak hayatlarını devam ettirmeleri öncelikle planlanmıştır. Mütevekkilin, yarının rızkını Allah'tan istememesinde, O'na duyduğu güvenin ve rızk kaygısı çekmemesinin rolü vardır. Bu durum, mütevekkilin kasr-ı emel sahibi olduğunu da ortaya koymaktadır.

Sehl b. Abdullah, sabah yemeğini yerken akşam ne yiyeceği, akşam yemeğini yerken de sabah ne yiyeceği endişesini taşıyan kimsenin tevekkülden nasibinin olmadığını söylemiştir. Allah'a tevekkül, acısıyla tatlısıyla kadere teslim olmayı; hayrın ve şerrin, Allah'ın adaletine ve hikmetine uygun olduğuna inanmayı gerektirir. İbn Abbas, “Kader, tevhid nizamıdır. Kim Allah'ın bir olduğuna inanır ve kaderi yalanlarsa bu, tevhid için noksanlıktır." 53 demiştir. Yapılan açıklamalar; tevekkülün, itikadî ve amelî yönlerinin olduğunu ortaya çıkarmıştır. Tevekkülün itikadî yönü; hayır ve şerrin Allah'tan olduğuna ve kadere inanmayı gerektirir. Tevekkülün amelî yönü ise; kader, hayır üzere tahakkuk ettiğinde de, şer üzere tahakkuk ettiğinde de başa gelenlere razı olmayı ve teslimiyet göstermeyi gerektirir. Allah, işlerin iç yüzünü en iyi bilendir. Hayır zannedilen şeylerin neticesi şer; şer zannedilen şeylerin neticesi de hayır olabilir. Hayır da, şer de birer imtihan vasıtasıdır. Şer geldiğinde, sabır, rıza ve teslimiyetle karşılanması, imtihandan sevap kazanarak çıkmaya ve şerrin hayra tebdil edilmesine sebep olabilir. Hayır geldiğinde, şükretmemek ve nimetin infakını yapmamak da, imtihanı kaybederek günah kazanmaya ve hayrın şerre tebdil edilmesine sebep olabilir.

Rabbini vekil kılan kimsenin, en doğru yolda gitmekte olduğunu söyleyen İbn Arabî, tevekkülü, nefsin dayandığı sebeplerin gerçekleşmemesiyle huzursuz olmayan bir kalbin Allah'a güvenmesi olarak tanımlamış ve kalp huzursuz olursa mütevekkil olunamayacağını belirtmiştir. ${ }^{54}$ Burada, kalbin niteliğinin belirtildiği görülmektedir. Tevekkülde, sadece kalbin güveni yeterli görülmemiş; kalbin, nefsin isteklerinin yerine gelmemesiyle huzursuz olmaması şartı da ortaya konulmuştur. Kalbin huzursuz olmaması; rıza halinde bulunması, huzur ve sükûn üzere olması demektir.

Tevekkül eden kimse, kendi çalışmasına, gücüne, gayretine veya bir başkasına değil de sadece Allah'a güvenmeli ve her şeyin sahibi yüce Allah'tan başkasında bir güç ve kuvvet görmemelidir. Ebû Abdullah Kureşî

53 Mekkî, age., II, s. 10.

54 İbn Arabî, age., III, s. 300. 
(599/1202), tevekkülün, Allah'tan başkasına sığınmayı terk etmeyi gerektirdiğini ifade etmiştir. ${ }^{55}$

Mekkî, tevekkül ehlinin, Allah'tan başkasına teveccüh etmeyeceğini, bağlanmayacağını, nefsin isteklerine uymayacağını ve kalbinin Allah'tan başkasıyla huzur bulamayacağını söylemiştir. Aksi davranışların, keşf ve müşahede mekânı olan kalbi esir alacağını, yakîni bozacağını ve her şeyin temeli olan imanı zayıflatacağını açıklamıştır. Mekkî, "Müşaheden artarsa, hırsın azalır ve halka tamahın kalmaz. Bu durum, rıza ve zühd halidir. Tevekkül, bu iki makamı da içine alır." demiştir. ${ }^{56}$ Müşahedenin artması, marifetin artmasıdır. Marifet sahibi olan kimse, Rabbini yakîn olarak tanıdığı için sadece O'na güvenir ve O'ndan gelen her şeye rıza gösterir. Rabbini yakîn olarak tanıyan kimse, halkın da kendisi gibi, Allah'a muhtaç olduğunu görerek onlara teveccüh etmez ve onlardan bir beklenti içerisine girmez. Bu durum, tevekkülün, hem zühdü, hem rızayı, hem de Allah'a teveccühü gerektirdiğini göstermektedir.

\section{Tevekkülün Dereceleri}

Mutasavvıflar, tevekkülü farklı şekillerde derecelendirmişlerdir. Bu dereceleri, aralarındaki benzerlikleri göz önüne alarak şu şekilde gruplandırmak mümkündür: 1. Avamın, havasın ve havassu'l-havassın tevekkülü. 2. Nefsten ve iradeden fâni olanların tevekkülü. 3. Şikâyeti terk edenlerin, kısmete rıza gösterenlerin ve muhabbet ehlinin tevekkülü.

\section{Avamın, Havasın ve Havassu'l-Havassın Tevekkülü}

Bu gurupta yapılan derecelendirmelerden birisi, avamın ve havasın tevekkülüdür. Her mü'min Allah'a tevekkül eder, fakat her kulun tevekkülü kendi yakîni kadardır. Havasın tevekkülü rıza; avamın tevekkülü ise hayrıyla, şerriyle kadere inanmaktır. ${ }^{57}$ Marifet arttıkça yakîn de artar. Marifeti ve yakîni üstün olan kimsenin dolayısıyla tevekkül derecesi de daha yüksek olur. Bu bakımdan havasın tevekküldeki derecesi, avamdan daha üstündür. Avamın tevekkülü, kaderde hayır ve şer olarak takdir edilen şeylerin gerçekleşeceğine inanmak iken, havasın tevekkülü, kadere inanmakla birlikte, takdir edilen şeyler tahakkuk ettiği anda başa gelen her şeye de rıza göstermektir. Havas içerisindeki kimselerin marifet ve yakîn seviyesinde farklılıklar olabileceği için,

\footnotetext{
55 Kelâbâzî, age., s. 119.

56 Mekkî, age., II, s. 5, 7.

57 Mekkî, age., II, s. 10.
} 
havastan olan kimselerin tevekkül derecelerinde de farklılıklar olacağı anlaşılmaktadır. Bu durum, havassu'l-havastan olan kimselerin tevekkül derecesinin daha da yüksek olacağını göstermektedir.

Ebû Yakub es-Sûsî, tevekkülde, avamın, havassu'l-avamın ve havassu'I-havassın tevekkülü olmak üzere üç makam bulunduğunu söylemiştir. Ona göre, kim, sebeplere sarılarak Allah'a tevekkül eder ve yakîn gerçekleşmezse, o avamdır. Kim, sebepleri terk ederek Allah'a tevekkül eder ve yakîn gerçekleşirse, o havassu'l-avamdır. Kim, yakîn halinin gerçekleşmesiyle sebeplerden sıyrılır ve daha sonra başkalarının faydası için tekrar sebeplere sarılırsa, o havassu'l-havastır. Bu en yüksek makamdaki özellikler, Hz. Peygamber'in cennetle müjdelenen ashabının özellikleridir. İbrahim Havvâs da, havasın, başkalarının rızkını temin etme görevi kendilerine verildiği için sebeplere sarıldığını, yoksa onların kalben sebeplere bağlanmaktan uzak olduğunu söylemiştir. ${ }^{58}$ Sûsî'nin, tevekkülün derecelerini makam olarak isimlendirdiği görülmektedir. Ayrıca, havassu'l- havassın sebeplere dönmedeki amaçları konusunda Sûsî ile Havvâs'ın ittifak ettiği de müşahede edilmektedir. Yapılan açıklamalardan, sebeplere sarılmanın yakîni engellediği anlaşılmaktadır. Avam, sebeplere sarıldığı için yakîn sahibi olamamıştır. Havas ve havassu'l-havas, sebepleri terk ettiği için yakîn sahibi olmuştur. Havassu'l-havassı, havastan ayıran özellik, sebeplere sarıldığı halde yakîn halinin zail olmamasıdır. Çünkü onlar, sebeplere kendileri için değil, başkaları için sarılmışlardır. Daha da önemlisi, sebeplere kalben değil bedenen sarılmışlar ve sebeplerin etkisinde kalmamışlardır. Sebepler onları değil, onlar sebepleri kullanmıştır. Bu durum gösteriyor ki, kalben sebeplere bağlanıp onların esaretine girmek tehlikelidir. Yoksa kalbî bir bağlantı olmaksızın bedenen sebeplere sarılmanın bir sakıncası yoktur.

Sülemî, mütevekkilin tabakalarını; mü'minlerin tevekkülü, havasın tevekkülü ve havassu'l-havassın tevekkülü olmak üzere üç kademeye ayırmıştır. Mü'minlerin tevekkülünü, Ebû Turab Nahşebî (ö. 245/859), "Bedeni ibadete vermek, kalbi rububiyetle meşgul etmek, tamamen Allah'a teveccüh etmek, verildiğinde şükretmek, verilmediğinde kadere rıza göstermek ve sabretmek." olarak açıklamıştır. Havasın tevekkülünü, Ebû Abbas b. Atâ (ö. 309/922), "Kim Allah'tan başkasıyla birlikte Allah'a tevekkül ederse, başkalarını bırakıp sadece Allah'a tevekkül etmedikçe tevekkül etmiş olmaz. Tevekkülünde başka bir sebep olmadığı zaman tevekkül etmiş olur.” diyerek açıklamıştır. Havassu'lhavassın tevekkülünü de, Cüneyd, "kalplerin bütün hallerde Allah'a güvenme-

58 Mekkî, age., II, s. 16, 17.

ÇÜIFD, 2018, cilt: 18, sayı: 1, ss. 131-165 
si" olarak açıklamıştır. Sehl b. Abdullah, bu son derecedeki tevekkül ehline, yakînin hakikati, gaybın keşfi ve kurbiyet verileceğini söylemiştir. 59

Sülemî, tevekkülün dereceleri yerine, "mütevekkilin tabakaları," avamın tevekkülü yerine de "mü'minin tevekkülü” ifadelerini kullanmıştır. İlk kademedeki mü'minlerin; vücutları ibadetle, kalpleri ise Allah'la meşguldür. Allah verdiğinde, şükreder, vermediğinde de kadere rıza göstererek sabrederler. Buradaki tevekkül anlayışı, tüm mü'minler için söz konusu olduğundan dolayı "mü'minlerin tevekkülü" şekilde isimlendirilmiş olabilir. Havasın tevekkülünde öne çıkan husus, tevekkülün Allah'a has kılınması ve tevekküle başkasının ortak edilmemesidir. Havassu'l-havassın tevekkülünde ise, her durumda Allah'a güvenilmesi öngörülmektedir. Bu tabakadaki mütevekkilin; kurb, yakîn, marifet ve keşf sahibi olmakla mükâfatlandırılacağı da anlaşılmaktadır.

Tevekkül, farz ve fazilet olmak üzere de iki kısımda mütalaa edilmiştir. Farz olan tevekkül, imana bağlıdır. Kadere teslim olmayı ve her şeyin, Allah'ın hükmü ile olduğuna inanmayı gerektirir. Bu durum, ayetlerde açıkça ifade edilmiştir: "Eğer Mü'min iseniz Allah'a tevekkül edin."60 "Eğer Allah'a iman ettiyseniz, O’na tevekkül edin, şayet Müslümansanız böyle yapın."61 Fazilet olan tevekkül ise, marifet makamındaki kişinin vekil olarak kabul ettiği Allah'ı müşahede etmesinden kaynaklanır. Bu kişi, Rabbine ve hakikatlere, aynel yakîn olarak bakar. ${ }^{62}$ Mekkînnin, belirtmiş olduğu bu derecelendirme, Sülemî'nin yaptığı derecelendirmenin ilk iki kademesine benzemektedir. Farz olan tevekkül, mü'minin tevekkülü ile fazilet olan tevekkül de havasın tevekkülü ile eşleşmektedir.

Havasın tevekkülünün özelliklerinden biri de, sözlü ve fiili eziyetler karşısında sabır göstermektir. Allah, “Öyle ise O'nu vekil edin ve onların söylediklerine sabret."63 diyerek bu durumlarda sabretmeyi peygamberine emretmiştir. Âriflerden birisi, halkın övmesiyle kötülemesi aynı olmadıkça ve onların eziyetine sabretmedikçe bir kimse tevekkül makamında kalamaz, demiştir. Sabırda tevekkül, halka güzel muamele etmeyi ve buna karşılık istememeyi gerektirir. ${ }^{64}$ Tevekküldeki sabrın, hem Hak'tan hem de halktan gelen eziyete sabretmeyi gerektirdiği anlaşılmaktadır. Allah rızası için yapılan iyiliklere, ne

\footnotetext{
59 Sülemî, el-Mukaddime fi't tasavvuf, s. 41, 42.

60 Mâide, 5/56.

61 Yûnus, 10/84.

62 Mekkî, age., II, s. 10.

63 Müzemmil, 73/9, 10.

64 Mekkî, age., II, s. 9.
} 
dünyevî ne de uhrevî bir karşılık beklenmemelidir. Ahiretteki mükâfatlar, beklenti içerisinde olunmasa da zaten bir ikram olarak Allah tarafından verilecektir.

\section{Nefsten ve İradeden Fâni Olanların Tevekkülü}

Tevekkül, nefsin isteklerini ve iradeyi terk etmeyi gerektirmektedir. Sehl b. Abdullah, "Tevekkül makamının evveli; kulun, Allah'ın önünde, gassâl önündeki meyyit gibi olmasıdır." 65 diyerek, tevekkülün, iradeyi terk etmeye bağlı olduğunu ifade etmiştir. Bu durumda, tevekkül sahibi, ölü gibi iradesini terk eden ve kendisini Allah'ın eline bırakarak O'nun yapacağı her şeye rıza gösteren kimsedir.

Tasavvuftaki makamları, usûl-ü aşere adıyla on temel prensipte inceleyen Necmüddin Kübra da (ö. 618/1221), tevekkülü, bir ölü gibi iradeyi terk ederek Allah'a güvenmek ve tedbirleri terk etmek olarak tanımlamıştır. Ruh bedenden ayrıldıktan sonra bedenin faaliyette bulunamadığı gibi iradeden fâni olan kimsenin de tedbiri terk ederek işleri Allah'a havale etmesi gerektiğini belirtmiştir. Necmüddin Kübra, bu tevekkül anlayışını "mutlak tevekkül” olarak adlandırmış ve tasavvuf eğitimi gören kimselere hasretmiştir. Normal kimselerin tevekkülünün ise tedbire ve sebeplere başvurduktan sonra söz konusu olduğunu açıklamıştır. ${ }^{66}$ Normal kimselerden kasıt avam; tasavvuf eğitimi gören ve ölü gibi iradesini terk eden kimselerin de havas olduğu anlaşılmaktadır. Avamın tevekkülünde, sebeplere sarılmak şart koşulurken, havasın tevekkülünde, sebepleri terk etmek şart koşulmuştur.

Sehl b. Abdullah'a, tevekkülün en aşağı mertebesinin ne olduğu sorulduğunda; "istek/arzu ve temenniyi terk etmek" diye cevap verir. Tevekkülün ortası nedir? Diye sorulduğunda; "iradeyi terk etmek" diye cevap verir. Tevekkülün en üst derecesi nedir? Diye sorulduğunda da; "Bunu ancak tevekkülün ortasında bulunup da iradesini terk eden bilir." diyerek cevap verir. ${ }^{67}$ Sehl'in ifadelerine bakıldığında, birinci derecede, nefsin isteklerinin terk edilmesi; ikinci derecede ise iradenin terk edilmesi gerektiği anlaşılmaktadır. Üçüncü dereceyi, iradesini terk eden bilir derken, kendisinin de iradesini terk edip de üçüncü dereceye geçenler arasında bulunmadığı ve iradeyi terk etmenin öyle kolay bir iş olmadığı ortaya çıkmaktadır.

\footnotetext{
65 Sülemî, el-Mukaddime fi't tasavvuf, s. 37.

66 Kübra, Necmüddin, Usûlu aşere, (Tasavvufî Hayat) Hazırlayan Mustafa Kara, Dergâh Yayınları, İstanbul 1996, s. 49, 50.

67 Mekkî, age., II, s. 4.
} 
Mekkî, "Kul, nefsinin arzu ettiği şeyi istese de, her yerde bulamaz. Mevlâ'nın iradesi ise, her şey için söz konusudur. Kula düşen, nefsinin iradesine değil, Mevlâ'sının iradesine tabi olmak ve O'nu tercih etmektir." demiştir. Bir haberde, Hz. Musa'ya şöyle vahyeddediği belirtilmiştir: "İstediğin olmadığı zaman, olanı iste (elinde olana razı ol). Eğer, istediğinin olması için diretirsen, seni yorarım. Neticede senin istediğin değil, yine benim istediğim olur."68 Bir şeyi istemekte direnmenin, yorgunluktan ve huzursuzluktan başka bir işe yaramayacağı, ancak elde mevcut bulunana ve Allah'ın verdiğine razı olunduğunda huzur ve sükûna ulaşılacağı anlaşılmaktadır. Tevekkülün, nefsin arzularının ve iradenin terkedilmesine bağlı olduğu ve buna göre de derecelendiği görülmektedir. Kulun, nefsini, iradesini terk etmesi ve yerine Allah'ın iradesinin hâkim olması, tevekkülde en üstün derece olsa gerektir. Çünkü kul, bu durumda, Allah'tan gelen her şeye rahatlıkla rıza gösterebilir.

Gazâlî, tevekkülün üç derecesi olduğunu söylemiş ve bu dereceleri, avukata, anneye ve gassâla duyulan güvene benzeterek açıklamıştır:

1. Avukata güvenmeye benzeyen tevekkül: Allah'ın kefilliğine ve yardımına güvenmek, müvekkilin vekiline/avukatına duyduğu güvene benzer. Vekilde; hidayet, kuvvet, fesahat ve merhametin zirvede olması gerekir. Bir kimse, Allah'tan başka fail olmadığına, O'nun ilmine, bütün varlıklara yetecek kadar şefkat ve merhamete sahip olduğuna, O'nun ilminin dışında bir ilim, merhametinin ve inayetinin dışında bir rahmet ve inayet olmadığına inanırsa sadece Allah'a tevekkül eder ve başkasına iltifat etmez.

2. Anneye güvenmeye benzeyen tevekkül: Bir kimsenin Allah'a karşı halinin, çocuğun annesine karşı olan hali gibi olmasıdır. Çocuk, annesinden başkasına güvenmez ve sığınmaz. Annesini gördüğünde eteğine yapışır, görmediğinde de "anneciğim" diyerek bağırır ve ondan yardım ister. Annesinin kefaletine ve şefkatine güvenir. Kim ki, kalbiyle ve fiiliyle, çocuğun annesine güvendiği gibi Allah'a güvenir ve O'nu yeterli görürse hakkıyla tevekkül etmiş olur.

3. Gassâla teslim olmaya benzeyen tevekkül: Bir kimsenin, hareketinde ve sükûnunda, gassâl önündeki meyyit gibi olmasıdır. Bu derecedeki kimsenin ölüye benzetilmesinin sebebi, nefsinden ve iradesinden fâni olmasıdır. Çocuktan farkı ise; ağlamasa da, istemese de kendisine kefil olan Allah'ın merhamet edeceğini ve gereken yardımı yapacağını bilmesidir. Gazâlî’ye göre, bu bilgi ve güvenle üçüncü derecedeki kimsenin, duayı ve istemeyi terk

68 Mekkî, age., II, s. 9. Nefs konusunda bkz. Kaplan, Hayri, İslam Düşünürlerine Göre Ruh ve Nefs (Yüksek Lisans Tezi, Ankara Üniversitesi Sosyal Bilimler Üniversitesi, 1995, s. 3.) 
etmesi caizdir. İkinci derecede tedbir tamamen ortadan kalkmaz. Çocuğun, annesine yapışması ve ondan yardım istemesi gibi, dua ve istek türünden tedbirlere başvurulabilir. ${ }^{69}$ Görüldüğü gibi, üçüncü derecede, tedbir ortadan kalkmakta, fakat ikinci derecede kısmen tedbire başvurulmaktadır. Birinci derecede ise, avukatın vasıflarının gözetilmesinde görüldüğü gibi, tedbire müracaat edilmektedir. Tedbire başvurmada, dereceler arasında farklılıklar olduğu hususunda, Gazâli'nin fikirleriyle Necmüddin Kübra'nın yukarıdaki fikirleri örtüşmektedir.

Gazâlî̀nin yaptığı derecelendirmede; birinci derecede ilmin, ikinci derecede, kurbun, üçüncü derecede ise fenânın ve marifetin tevekkül üzerinde etkili olduğu anlaşılmaktadır. Tevekkülün kemalinde; Allah'ın gücünü ve kudretini bilmenin, ibadetlerle ve taatla O'na yaklaşmanın, nefsin arzularını ve iradeyi terk ederek tamamen O'na teslim olmanın rolü görülmektedir. Üçüncü derecede, tedbirin ortadan kalkmasında fenâ halinde olmanın tesiri vardır. Bu derecede, tevekkülden de, masivânın dışındaki her şeyden de fenâ söz konusudur. Fenâ halinde Allah'tan başkasına teveccüh etmek ve O'ndan başkasını murad etmek düşünülemez.

İbn Arabî, mütevekkillerin, tevekkül hallerindeki farklılıkları şu şekilde ifade etmiştir: Bu makamla nitelenenlerin bir kısmı; Allah'ın önünde, "gassâl önündeki meyyit" gibidir. Yıkayıcı (gassâl), onu dilediği gibi çevirir ve o itiraz etmez. Onlardan bir kısmının hali; efendisinin malında kölenin hali gibidir. Onlardan bir kısmının hali, babasının malında çocuğun hali gibidir. Onlardan bir kısmının hali de, müvekkile karşı vekilin hali gibidir. ${ }^{70}$

Tevekkül makamındaki bir kimsenin, Allah'a karşı, gassâl önündeki meyyit gibi olması; mütevekkilin, Allah'ın hükmü, lehine tahakkuk ettiğinde de, aleyhine tahakkuk ettiğinde de itiraz etmemesi ve durumu kabullenmesidir. Bu durumdaki mütevekkil, kendi istek ve iradesinden fâni olmuş ve Allah'ın iradesine teslim olmuştur. İlahi irade, kendi iradesinin yerine kâim olduğu için, Allah'ın iradesi karşısında tam bir teslimiyet ve rıza gösterir. Bu durumdaki mütevekkil, ölü gibi iradesini terk etmiştir.

Tevekkül makamındaki kimsenin halinin, efendisinin malında kölenin hali gibi olması; mütevekkilin, Allah'ın direktiflerine uygun hareket etmesi ve O'nun izin vermediği davranışları sergilememesidir. Köle, efendisinin kullanımına izin verdiği malı, onun belirlediği hususlara riayet ederek kullanır. Mütevekkilin hali de kölenin hali gibidir. Allah'ın mülkünü, O'nun belirlediği kurallara

69 Gazâlî, Ihya, IV, s. 324, 325.

70 İbn Arabî, age., III, s. 301.

ÇÜiFD, 2018, cilt: 18, sayı: 1, ss. 131-165 
riayet ederek O'nun istediği gibi kullanır. Köle, efendisinin istediği şekilde hareket etmesi gerektiği halde, onun istemediği şekilde hareket etmek ve onun istemediği şeyleri yapmak iradesine de sahiptir. Sonradan alacağı cezayı bilmesine rağmen bu iradesini kullanarak istediği şeyi yapabilir. Bu durumdaki mütevekkilin hali de kölenin hali gibidir. Allah'ın vereceği cezayı göz ardı etmeden iradesini menfi yönde kullanarak Rabbinin istemediği şeyleri de yapabilir.

Tevekkül makamındaki kimsenin halinin, babanın malında çocuğun hali gibi olması; mütevekkilin, malı kullanmada daha esnek durumda olması ve daha rahat davranması demektir. Halk arasında ifade edilen, "babasının malı gibi kullanıyor" deyimi ile de bu durum daha rahat anlaşılabilir. Çocuk, babasının malını, kendi malı gibi kullanır, fakat bu kullanım, sorumsuz ve pervasız bir kullanım demek de değildir. Babaya duyulan saygı, onun karakterine, isteklerine ters düşmeyecek ve bunlardan sakınılacak bir davranış sergilemeyi gerektirir. Çocuk, babasının malını, onun kızacağı veya ona karşı mahcup olacağı şekilde kullanmaktan çekindiği gibi mütevekkil de, Allah'ın mülkünü, Onun istemediği ve O'na karşı mahcup olacağı şekilde kullanmaktan çekinir. Bu konumdaki mütevekkil, her ne kadar çekinceleri olsa da daha rahat kullandığı bir iradeye sahiptir. Bu iradesiyle, istenmeyen şeyleri, köleden daha rahat bir şekilde yapabilir.

Tevekkül makamındaki kimsenin halinin; müvekkile karşı vekilin hali gibi olması; vekilin, müvekkilin verdiği yetkiyle dilediği her tasarrufu yapabileceği anlamındadır. "Vekil, asil gibidir." deyimi, vekilin, müvekkilinin malını kullanmada mal sahibinden farksız olduğunu göstermektedir. Vekilin yetkisi, hususi vekâletle belirli konularla sınırlandırıldığı gibi, umumi vekâletle de sınırsız hale getirilebilir. Bu durumdaki vekil, müvekkile karşı sorumlu olmakla birlikte daha geniş kullanabileceği bir iradeye sahiptir.

İbn Arabî'nin burada, tevekkül ehlini bir derecelendirmeye tabi tuttuğu görülmektedir. Bu derecelendirme, iradenin kullanımıyla ilişkilendirilmiştir. Tevekkülde, teslimiyetin tam olabilmesi için, iradenin terk edilmesinin gerekliliği ortaya çıkmıştır. Tevekküldeki derecelendirme de, iradenin terkiyle orantılı bir şekilde yapılmıştır. Gassâl önündeki meyyit gibi iradesini yok eden mütevekkil birinci mertebededir. Köle gibi iradesini çok az kullanabilen mütevekkil, ikinci mertebededir. İradesini, babasının malı gibi rahat ve daha çok kullanan mütevekkil, üçüncü mertebededir. İradesini, vekil gibi dilediği şekilde kullanan mütevekkil de dördüncü mertebededir. 


\section{3. Şikâyeti Terk Edenlerin, Kısmete Rıza Gösterenlerin ve Muhabbet Ehlinin Tevekkülü}

Yahya b. Muaz (ö. 258/871), tevekkülün; şikâyeti terk etmek, kısmete rıza ve muhabbet olmak üzere üç derece olduğunu söylemiş ve bu derecelerin birincisinin Salihlerin, ikincisinin ebrarın, üçüncüsünün de Peygamberlerin tevekkülü olduğunu açıklamıştır. ${ }^{71}$ Şikâyeti terk etmeden rıza sahibi olmak zaten mümkün değildir. Hz. Ali, "Kim rıza yaygısı/sergisi üzerine oturursa (rıza halinde olursa), kendisine ebediyyen bir sıkıntı ulaşmaz. Kim de devamlı olarak neden, niçin? Şeklinde ilâhî hüküm ve tecelliler hakkında sual sorma derdine düşmüşse, o da hiçbir şekilde Allah'tan razı olamaz." demiştir. ${ }^{72}$

Tevekkülün bu üç derecesinin birbiriyle bağlantısı vardır. Şikâyeti terk etmeyen kimse kısmete razı olamayacağı gibi, kısmete razı olmayan kimse de muhabbet ehli olamaz. Üçüncü derecedeki muhabbet ehli, hem şikâyeti terk eden hem de kısmete razı olan kimsedir. Her derece, kendinden sonraki dereceye basamak teşkil etmekle birlikte farklı anlamlar da taşımaktadır. Birinci derece olan şikâyeti terk etmek, sabrın özelliğidir. Sabır; şikâyetçi olmaksızın sükûnetle beklemek, tahammül etmek ve nefse hâkim olmak anlamlarına gelmektedir. ${ }^{73}$ Muhâsibî, "Sabır, ilâhî buyruklar karşısında kıpırdamadan durmaktır." 74 diyerek sabırda şikâyete yer olmadığına işaret etmektedir. Cüneyd, "Sabır, yüzünü ekşitmeden acıyı yudum yudum içine sindirmektir."75 diyerek sabırda, olayın verdiği acıyı veya memnuniyetsizliği aksettirecek en ufak bir hissiyata dahi yer olmadığını ifade etmiştir.

İkinci derece kısmete rızadır. Rıza, kızmak ve hoşlanmamak kelimelerinin zıddıdır. Hoşnut ve memnun olmak anlamlarına gelmektedir. ${ }^{76}$ Sabırda, başa gelen musibetin acısına tahammül edip şikâyeti terk etmek varken; rızada, başa gelen musibetten ve etkisinden hoşnut olmak da vardır. Rızada, Allah'tan gelen nimeti de musibeti de, "lütfun da hoş, kahrında hoş" anlayışıyla hoş görmek vardır. Allah'ın belirlediği ve uygun gördüğü kısmeti uygun görmemek ve beğenmemek rıza anlayışına uygun bir davranış değildir. Rabiatü’l-

\footnotetext{
71 Sülemî, el-Mukaddime fi't tasavvuf, s. 40.

72 Sühreverdî, Ebû Hafs Şihabüddin Ömer b. Muhammed, Avârifü’l-meârif, I-II, thk. Abdülhalîm Mahmud, Muhammed İbn Şerîf, Dâru'l-maârif, Kahire ts. II, s. 294.

73 Ahmed el-Âyid ve diğerleri, age., s. 717.

74 Schimmel, Annemaria, Tasavvufun Boyutları, Adam Yayınları, İstanbul 1982, s. 115.

75 Kuşeyrî, er-Risâletü'l-Kuşeyriyye, s. 183.

76 İbn Manzûr, age., III, s. 1663.
}

ÇÜiFD, 2018, cilt: 18, sayı: 1, ss. 131-165 
Adeviyye (ö. 185/801), rıza mertebesine ancak, Allah'ın nimeti kadar musibetinden de memnun olunduğu zaman ulaşılabileceğini belirtmiştir. ${ }^{77}$.

Tevekküldeki üçüncü ve en yüksek derece ise muhabbettir. Semnûn Muhib (ö. 320/932), "Hak Teâla'ya giden yolun aslı ve esası muhabbettir. Haller ve makamlar, birtakım konak yerleridir. Muhabbet makamı ve mahalli müstesna talibin bulunduğu mahallin ondan zail olması caizdir. Fakat muhabbet mahalli ve makamı yol mevcut olduğu sürece ondan zail olmaz." demiştir. Hucvirî (ö. 470/1077), diğer şeyhlerin tamamının da bu hususta Semnûn'la aynı görüşü paylaştıklarını belirtmiştir. ${ }^{78}$ Muhabbetin, tevekküldeki en üst derece olması fikri, muhabbetin, bazı kimseler tarafından en son makam olarak kabul edilmesinden kaynaklanabileceği gibi; Semnûn'un ifadesinde görüleceği üzere, muhabbetin, her makamda olması gereken bir haslet olmasından da kaynaklanmış olabilir.

Tevekkülde en yüksek derece olarak görülen muhabbet, peygamberlerin tevekkülü olarak isimlendirilmiştir. Hz. Muhammed'in, Habibullah sıfatı ve Hz. İbrahim'in Halilullah sıfatı, bu derecelendirmenin sıhhatine işaret etmektedir. Peygamberler, Allah sevgisinin en yüksek olduğu kimselerdir. Onlardaki muhabbet, Allah hakkındaki marifetlerinin ve yakînî imanlarının neticesidir.

Beyazid Bistâmî'nin ifade ettiği gibi, muhabbet, kendi yaptığı çok şeyi az görmek ve dostun yaptığı az şeyi çok görmektir. ${ }^{79}$ Peygamberlerin işi terakkidir. Hz. Peygamber'in, günde yüz defa tevbe etmesinin ${ }^{80}$ sebebi, bir dereceye yükseldiği zaman, önceki derecelerin kendisine basit görünmesi olabilir. ${ }^{81} \mathrm{Bu}$ durum, Habibullah olan Hz. Peygamber'in, dostu için daha önce yaptıklarını az görerek tevbe ettiği düşüncesini ortaya çıkarmaktadır. Peygamberlerin sahip olduğu, tevekküldeki muhabbet derecesi, sevdikleri için yaptıklarını az görmelerinin yanında, hiçbir kimsenin tahammül edemeyeceği sıkıntılara

77 Kuşeyrî, er-Risâletü'l-Kuşeyriyye, s. 195.

78 Hucvirî, age., s. 552. Buradaki ifadelerden, muhabbetin, hem makam hem de hal olarak algılandığı anlaşılmaktadır. Schimmel (ö. 2003), havf ve recânın hal mi yoksa makam mı olduğu konusunda mutasavvıfların ihtilaf ettiğini, Serrâc'ın (ö. 378/988) bunları hal olarak kabul ettiğini, ancak bunları psikolojik açıdan makam olarak değerlendirmek gerektiğini söylemiştir. Schimmel, genellikle havf ve reca ile birlikte zikredilen muhabbeti de makam olarak ifade etmiştir. Muhabbet ve marifetin birbirini tamamladığını ve tasavvuf yolundaki son makamlar olduğunu belirtmiştir. ${ }^{78}$ Serrâc, muhabbeti de havf ve recâ gibi haller arasında zikretmiş ve incelemiştir. ${ }^{78}$ Hucvirî de muhabbetin kesbî değil vehbî olduğunu söylemiş ve muhabbeti hal olarak zikretmiştir. ${ }^{78}$

79 Hucvirî, age., s. 452.

80 Müslim, Ebu'l-Huseyn Müslim b. el-Haccâc el Kuşeyrî, Sahih, I-V, nşr. Muhammed Fuâd Abdülbâkî, Dâru İhyâi'l-Kütübi'l- Arabiyye, Kahire 1991, Zikir, 41.

81 Gazâlî, Kimyâ-yı Saâdet, çev. Mehmed A. Müftüoğlu, İstanbul 1981. s. 525. 
katlanmalarına ve daima dostlarına güvenmelerine de sebep olmuştur. Allah da, muhabbet tevekkülü ile kendisine güvenen ve bağlanan dostlarına daima yardım etmiş ve İbrahim Peygamber'e ateş içinde esenlik verdiği gibi, şerleri hayra tebdil ederek sıkıntılarını saadete çevirmiştir.

Sülemî̀nin, tevekkülü daha detaylı bir derecelendirmeye tabi tuttuğu ve bu derecelendirmede tevekkülün nasıl yapılacağını da açıkladığı görülmektedir. Sülemî, tevekkülün en aşağısının rızkta Allah'a güvenmek olduğunu, bunun esasının da mâsivâdan yüz çevirerek Allah'a teveccüh etmek, O'ndan başka zarar ve fayda verecek bir şey görmemek olduğunu söylemiş ve bundan sonraki derecelendirmeyi ve yapılacak işleri şu şekilde sıralamıştır: Yakîn sahibi olmak, Allah'a güvenmek, işleri O'na bırakmak (tefviz), başa gelecek olan iyi veya kötü her şeye razı olmak, bela ve musibetlere katlanmak, nimetten huzur duyduğu ve lezzet aldığı gibi hatta daha çok belalardan lezzet almak, zahiren ve bâtınen kadere rıza göstermek, Hakk'a ve Hak ehline sarılmak, Müslümanlara saygı göstermek ve halka Hak gözüyle bakmak. ${ }^{82}$

Sülemî'nin derecelendirmesinin son kısımları, başa gelenlere yani kadere rıza olarak bir madde halinde ifade edilebilir. Bu durumda yapılan derecelendirmeyi şu şekilde maddelemek mümkündür: 1. Rızkta Allah'ın kefilliğine güvenmek. 2. Yakîn sahibi olmak. 3. Her konuda Allah'a güvenmek. 4. İşleri O'na havale etmek (tefviz). 5. Kadere rıza göstermek.

Sülemî'nin açıklamalarında, nimete şükür ve kısmete rıza ifade edildiği gibi rızanın, nimetlerden daha çok musibetlerden zevk almayı gerektirdiği de vurgulanmıştır. Sülemî'nin bu ifadelerinin, Rabia'nın, “Kul, rıza mertebesine, nimetlerden zevk alındığı gibi musibetlerden de zevk alındığı zaman ulaşıIır." sözüyle örtüştüğü görülmektedir. Hatta Sülemî'nin bir adım daha öteye giderek rızanın şartlarına "nimetten daha çok musibetten zevk almak" maddesini de eklediği görülmektedir.

\section{Tevekkül-Vahdet İlişkisi ve Tevekkülü Terk Etmek}

İbn Arabî, tevekküle farklı bir bakış açısı getirmiş ve konuyu vahdet anlayışına uygun bir şekilde işlemiştir. İbn Arabî, Allah Teâlâ'nın, Hz. Musa'ya, "Ey insanoğlu! Eşyayı senin için, seni ise kendim için yarattım." diye vahyettiğini belirtilmiş ve bu söze binaen, eşyanın kendisi için yaratıldığını bilen kimsenin şu tespitlerde bulunacağını ifade etmiştir: Eğer Allah, bir şeyi benim için yarattıysa, o benim menfaatime uygundur. Ben bir şeyi kullandı-

82 Sülemî, Sülemî, Ebû Abdirrahmân Muhammed b. Hüseyin, Sülemî'nin Risaleleri, Çev. Süleyman Ateş, Ankara Üniversitesi Basımevi, Ankara 1981, s. 116. 
ğımda, onun beni mutlu edip etmeyeceğini bilemem. Allah, benim menfaatime uygun olan şeyi en iyi bilendir. ${ }^{83}$ İnsan, yaptığı bir şeyin sonucunun lehine mi yoksa aleyhine mi tecelli edeceğini bilemez. Başına gelen bir şeyin, faydasına mı, yoksa zararına mı olduğunu da bilemez. Allah'ın takdiri, insan için gaybtır. Gaybı bilen ancak Allah'tır. Her şeyi yaratan ve seyrini tasarrufuyla yöneten Allah, kulu için hangi şeyin uygun olduğunu da en iyi bilendir.

İbn Arabî'ye göre; Allah, kendisini, yarattığı her şey yerine koymuştur. Çünkü $O$, her halde ve durumda kendisine muhtaç olunandır. Allah, bu durumu, mü'min ve mü'min olmayan herkese hitaben "Ey insanlar! Siz Allah'a muhtaçsınız. Allah ise zengindir/muhtaç değildir ve övülmeye lâyıktır."84 diyerek ifade etmiştir. İbn Arabî, "Allah, kendisini, yarattığı her şey yerine koydu." sözünü ve ayeti şu şekilde yorumlamıştır: "Sizin muhtaç olduğunuz şeyler bizimdir, bizim elimizdedir ve bize aittir. Bu sebeple, ancak bizden istenir. Siz eşyaya değil, bize muhtaçsınız. Çünkü eşya, kendi başına müstakil değil, aksine bizimledir." 85

İbn Arabî'nin, "Muhtaç olduğunuz şeyler bizimdir, bizim elimizdedir." sözünde, eşyanın varlığı söz konusu edilmiş ve insanların eşyayı görmelerinin, bir yanılgı olduğu ortaya konulmuştur. Bu anlayışta, vahdet-i şuhûd bulunduğu düşünülebilir. İbn Arabî, "Eşya kendi başına müstakil değil, aksine bizimledir." ve "Allah, kendisini, yarattığı her şey yerine koymuştur." sözleri ile de, varlığın birliğine, yani vahdet-i vücûda işaret etmiştir. Her ne kadar, vahdet-i şuhûd ve vahdet-i vücûddan bahsedilmese de burada, vahdet-i şuhûddan kademeli olarak vahdet-i vücûda geçildiği düşünülebilir.

İbn Arabî, şiirinde, "Sen sahibi olduğun mülkte vekilsin. Tevekkülü terk; insan olsun, melek (Cibrîl) olsun vekilin (Allah'ın) dışındaki kimsenin bilemeyeceği bir haldir. Tevekkül nasıl olacak ki? Varlıklar Allah'ın zatının dışında değildir. Ne varlık vardır, ne de varlığın eseri..." diyerek varlıkların, Allah'ın zatının dışında vücutlarının olmadığını, Allah'tan başka varlık olmadığını, olmayan bir şeyin tevekkül etmesinin de düşünülemeyeceğini ifade etmiş ve bu konuda da vahdet-i vücûd görüşünü güçlü bir şekilde dile getirmiştir. İbn Arabî, madumun, yani yok olan (mevcut olmayan) bir kimsenin nitelendirileceği bir makam olmadığını ve gerçek tevekkülün, var olanda gerçekleşebileceğini söylemiştir. Buna rağmen, tevekkülle nitelendirilen madum var olduğunda

83 İbn Arabî, age., III, s. 300.

84 Fâtır, 35/15.

85 İbn Arabî, age., III, s. 301. 
da, tevekkülün ondan çıkacağını ve bunun tevekkülü terk etmek olduğunu belirtmiştir. ${ }^{86}$

Burada, hakiki tevekkül, vahdet-i vücûd görüşüne göre değerlendirilmiştir. Allah'ın zatından başka varlık olmadığı için, olmayan kimsenin tevekkülünden bahsetmenin de söz konusu olamayacağı belirtilmiştir. Tevekkülle nitelenen madum/olmayan kimse, var olduğunda tevekkülün ondan çıkacağı, tevekkülü terk etmenin de bu olduğu ifade edilmiştir. Madumun, var olması; fenâdan sonra bekâ ile izah edilebilir. Kul, Allah'tan başka hakiki varlık olmadığını bilerek halktan, nefsinin isteklerinden ve iradesinden fâni olarak gerçek varlıkla beraber olur. Allah da, yokluğunun farkına vararak halktan fâni olan kulunu kendisiyle var eder. Kulun, Allah'la var olmasıyla hakiki tevekkül de gerçekleşir, fakat bu durumdaki kul, ihtiyacı olmadığı için tevekkülü terk eder. Bekâ konumundaki kul, kendi iradesi yerine Allah'ın iradesi kaim olduğu için, bu iradenin dışında hareket etmez. Daima Allah'la olan ve O'nun iradesine tabi olan kimse, O'ndan başka hiçbir şeye ihtiyaç duymaz.

İbn Arabî, hakiki tevekkül mevcut olduğu halde dünyada gerçekleşemez, demiş, fakat tevekkülün şeriatta mevcut olduğunu ve tevekkülün dindeki bu kısmına ulaşılabileceğini söylemiştir. ${ }^{87}$ İbn Arabî, varlık ve vahdet-i vücûd teorisine dayanarak hakiki tevekkülün olamayacağından bahsederken tevekkülü tamamıyla reddetmemiş ve dinde tevekkülün olduğunu, dinin önerisine göre de tevekkül edilmesi gerektiğini ifade etmiştir. Bu düşünceye göre tevekkülü; hakiki ve mecâzî, zahirî ve bâtınî, olmak üzere tasnif etmek de mümkündür.

İbn Arabî, Allah dostlarından iki (çeşit) adam dışında, avamın/halkın bildiği tevekkülü terk etmenin doğru olmadığını söylemiş ve şu açıklamayı yapmıştır: Birinci kişi: Tevekkülün gerçekleşmeyeceğini bilir ve onu terk eder. Çünkü o, nefsinin halini görünce tevekkülü elde edemeyeceğini bilir. Bir kişinin açlık acısı çektiğinde, bu acıyı gidermek için elinde bulunan şeyi yemesi ve hasta olan kimsenin doktora gitmesi gibi. İkinci kişi: Allah, yarattığının menfaatini en iyi bilendir. Öyleyse ne için tevekkül edilecek ki? Diyerek tevekkülü terk eder. Bununla birlikte bu kişi, emir ve nehye uyarak amel eder ve dinin hükümlerini yerine getirir. Tevekkülün terki, tevekkülün sırlarındandır. Bir kimse, eğer tevekkülü terk ederse, ağyarı (Allah'ın dışındakileri) terk eder. Tevekkül, mâsivânın varlığını kabul etmez (yok sayar). ${ }^{88}$

\footnotetext{
86 İbn Arabî, age., III, s. 302.

87 İbn Arabî, age., III, s. 301.

88 İbn Arabî, age., III, s. 301.
} 
Yapılan açıklamalara göre tevekkülü; avamın tevekkülü ve havasın tevekkülü şeklinde de tasnif etmek mümkündür. Buradaki tevekkülden kastedilen, dinin önerdiği ve halkın/avamın bildiği tevekküldür. Tevekkülü terk eden kişiler de, madum değil mevcut kişilerdir. Birinci kişinin tevekkülü terk etme sebebi; nefsine yenik düşmesidir. Bu kişi, dinin istediği davranışı sergilemeyen ve tevekkülü terk ederek, tevekkül etmeyen kişidir. İkinci kişinin tevekkülü terk etme sebebi; Allah'ın, faydasına olan şeyi kendisinden daha iyi bildiğini idrak etmesidir. Bu anlayışla tevekkülü terk etmek, dinin önerisiyle örtüşmektedir. Tevekkülü, bu şekilde terk eden kişi, aslında kendisini tamamen Allah'ın ellerine bırakarak daha derunî bir tevekkül anlayışı sergilemiştir. Bu kişi, birinci kişinin aksine, tevekkülü terk ederek tevekkül etmiştir.

\section{Tevekkülün Zamanı}

Her konuda olduğu gibi tevekkül konusunda da en büyük örnek $\mathrm{Hz}$. Peygamberdir. Tevekkülün, işe başlamadan önce mi, yoksa iş için gerekli gayret ve çabayı gösterdikten sonra mı yapılması gerektiği hususunda oluşabilecek tereddütleri gidermek ve tevekkülün zamanını anlamak için onun uygulamalarına göz atmak gerekir.

"Eğer Allah'a hakkıyla tevekkül etseydiniz, karınları aç olarak gidip tok olarak dönen kuşlara rızık verdiği gibi size de rızık verirdi." ${ }^{99}$ hadisinde, tevekkülün, iş için gereken gayret ve çabayı sarf etmeden önce yapılmasına işaret edilmiştir.

Ey Allah'ın Resulü, devemi salıyor ve öyle tevekkül ediyorum, ne dersiniz? Diyen kimseye Hz. Peygamber, "Hayır, deveni bağla ve öyle tevekkül et." 90 diyerek cevap vermiştir. Bu hadiste ise tevekkülün, gereken tedbirler alındıktan sonra yapılması gerektiğine işaret edilmiştir.

"Bir kimse evinden çıkarken besmele ile birlikte 'Allah'a tevekkül ettim, Allah bana yeter, $O$, ne güzel vekildir.' derse, ona şöyle cevap verilir: hidayete yöneltildin, ihtiyacın giderildi ve Şeytan'dan uzaklaştırıldın." ${ }^{91}$ hadisinde, tevekkülün güne başlarken, yani işin henüz başlangıcında yapılmasına işaret edilmiştir. Yukarıda, örnek verilen hadiste ise, "Deveni bağladıktan sonra tevekkül et." denilmiştir. Bu hadisler, birbirine tezat teşkil etmeyip, birbirini ta-

89 Tirmizî, Zühd, 33; İbn Mâce, Zühd, 14; Ahmed b. Hanbel, Müsned, thk. Şuayb el-Arnavût vd., I-VIII, Müessesetü'r-risâle, Beyrut 2001, I, 332; Beyhakî, Ebû Bekr Ahmed b. el-Huseyn, Şuabu'l-iman, I-VIII, Beyrut 1410, II, 66.

90 Aclûnî, İsmâil b. Muhammed el-Cerrâhî, Keşfu'l-hafâ, I-II, Beyrût 1405, I, 144.

91 Ebû Dâvûd, Edeb, 102. Tirmizî, Deavât, 34. 
mamlamakta ve tevekkülün, işin başında da, sonunda da yapılması gerektiğini ortaya koymaktadır. Ferit Kam'ın (1944), şiirinde de tevekkülün işten önce yapılması üzerinde durulmuştur.

Evvel Allah'a tevekkül eyle, sonra esbaba tevessül eyle,

Matlabın (isteğin) hâsıl olursa şükret, şayet olmazsa tahammül eyle. ${ }^{92}$

Hadislerden ve şirden, işin başında da, ortasında da, sonunda da, tevekkül etmek gerektiği anlaşılmaktadır. Tevekkül, mutlak bir güven ve teslimiyet gerektirmektedir. Bu güven ve teslimiyetin işin belirli bir zamanına hasredilmesi, diğer zamanlarda güvenmemek anlamına gelebilir. Yukarıda örnek verilen hadislerde, tevekkülün zamanına işaret edilmesiyle birlikte tevekkülün şartlarına da işaret edildiği görülmektedir.

Tevekkülün, işin başında, ortasında veya sonunda yapılması kadar, hangi durumlarda yapılması gerektiği de önemlidir. Muhâsibî, "Her ihtiyaç anında Allah'tan yardım iste. Her durumda O'na intiyaç duy. Her işte O'na tevekkül et." 93 diyerek, tevekkül edilecek iş ve zaman hakkında açıklama yapmıştır. Bu durum, tevekkülün, kulun her işini ve her anını kapsadığını ortaya koymaktadır.

\section{Tevekkülün Kazanımları}

Tevekkül etmeyen kimselerin kaybı, tevekkül eden kimselerin ise kazanımları çoktur. Bu kayıplar ve kazanımlar, hem dünyevî hem de uhrevî hayat için söz konusudur.

Allah, herkesin rızkını ezelde belirlemiştir. Bu değişmeyecek olan taksimi beğenmeyenler küfre girebilirler. Rızkın değişmeyeceğini bile bile hırsla rızık peşinde koşmanın sonu, dünyada zillet ve yorgunluk, ahirette de hüsrandır. Rızk gibi ömür de Allah'ın takdir ettiği kadardır. Allah'ın bilgisinde olan bu hususlar insanlar için gaybtır. Bu gerçeği bilmek, insanları rızk konusunda ikna etmeli ve sakinleştirmelidir. Allah'ın kefil olduğu rızk, kulun hayatını sürdürebileceği ve ibadet edebileceği kadardır. Tevekkül eden kimsenin, bu konuda tasalanmasına gerek yoktur. Allah, dilediğini yapmaya kâdirdir. Dilerse yiyecekler ve içeceklerle, dilerse bunlar olmadan da kulunu ayakta tutabilir.

\footnotetext{
92 Uludağ, Tasavvuf Terimleri Sözlüğü, s 488.

93 Muhâsibî, Ebû Abdullah Hâris b. Esed, Risâletü'l-müsterşidin, Dâru'l-Beşâiri'l-İslâmiyye, Beyrut 2014, s. 193.
} 
Açlıktan ölenler, çok yemekten ve hazımsızlıktan ölenler gibi ecellerinin gelmesiyle ölürler. ${ }^{94}$

Allah'ın, hayatını sürdürebileceği rızk konusunda kefil olduğunu bilmek tevekkül sahibinin rızk kaygısını giderir ve onu rahatlatır. Böyle bir bilgiye sahip olmak ve inanmak, marifete ve yakînî bir imana ulaşmak demektir. Tabii ki bu durum, takdir edilmiş olan rızkı evde beklemeyi değil, onu elde etmek için gereken çabayı göstermeyi de gerektirir. Kul için gayb olan kader, Allah'ın bilgisi dâhilindedir. Kulun rızkı, kaderde belli olduğu gibi, onun rızkı elde etmek için göstereceği çaba da kaderde bellidir. Sadece takdir edilmiş olan rızkı kader olarak görüp, rızka ulaşmak için gösterilmesi gereken çabayı göz ardı etmek, kader anlayışına terstir. Allah'ın bilgisi dâhilinde olan kader, hem kulun rızkı hem de rızk için göstereceği çaba ile ilgilidir. Tevekkülün sıhhati, kader anlayışının sıhhatine de bağlıdır.

Hz. Peygamber, "Kendini beğenmeyen, böbürlenmeyen, uğursuzluğa inanmayan, hırsızlık yapmayan ve Rabbine tevekkül eden kimselerin hesaba çekilmeden cennete gireceklerini" müjdelemiştir. ${ }^{95}$ Hadisten anlaşılacağı üzere, sorguya çekilmeden cennete girmenin yollarından birisi de tevekküldür.

Allah'a güvenmek ve tevekkül etmek, O'nun sevgisine ve yardımına kavuşmaya sebep olur. Gazâlî, "Kararını verdiğin zaman artık Allah'a dayan/tevekkül et. Çünkü Allah, kendisine dayanıp güvenenleri/tevekkül edenleri sever."96 ayetine dayanarak tevekkülün, sahibini Allah sevgisi ile şereflendiren ve O'nun desteği ile müjdeleyen çok yüce bir makam olduğunu söylemiştir. Allah'ı, kendisine koruyucu, destekleyici, sevgili ve gözetici olarak gören kimsenin kurtuluşa ermiş olduğunu belirtmiş ve sevilen kimsenin, seven tarafından eziyet görmeyeceğini, kovulmayacağını ve mahcup edilmeyeceğini müjdelemiştir. ${ }^{97}$ Allah'ın sevgisine, farzları yaparak, nafileleri artırarak yaklaşmak suretiyle ulaşılacağı; Allah'ın da, sevdiği kullarını, gözetimi ve koruması altına alacağı ${ }^{98} \mathrm{~Hz}$. Peygamber'in hadisinde de yer almaktadır.

94 Gazâlî, Minhâcü'l-âbidîn, s. 230, 231, 232.

95 Ahmed b. Hanbel, Müsned, IV, 222; İbn Hibbân, Ebû Hâtim Muhammed b. Ahmed el-Bustî, Sahîhu İbn Hibbân, I-XVIII, Müessesetü'r-risâle, Beyrut 1998, XIV, 340; Taberânî, Ebû'IKâsım Süleyman b. Ahmed b. Eyyûb, el-Mu'cemu'l-kebîr, I-XXV, Mektebetü İbn Teymiyye, Kahire 1994, X, 6; Ebû Ya'lâ Ahmed b. Ali el-Musennâ, Müsned, I-VIII, Dımeşk 1984, IX, 233.

96 Âl-i İmrân, 3/159.

97 Gazâlî, Mükâşefetü'l-kulûb, s. 248.

98 Buhârî, Ebû Abdullah Muhammed b. İsmâil el-Cu'fî, Sahîhu'l-Buhârî, I-VII, Beyrût 1410/1990, Rikâk,38; Ahmed b. Hanbel, Müsned,VI, 256. 
Zikredilen ayet ve hadise bakıldığında; Allah'ın sevgisine, tevekkülle, farz ve nafile ibadetleri yapmakla kavuşulacağı anlaşılmaktadır. Allah'ın sevgisine kavuşmak, her iki cihanda da kurtuluşa ermek demektir. Dünyada, Allah tarafından korunup gözetilmenin ve ahirette de cennetle mükâfatlandırılmanın yolu Allah'ın sevgisine ulaşmaktan geçmektedir. Allah'ın da, tevekkül ederek sadece kendisine güvenen kulunun güvenini boşa çıkarmayacağı, onu iki cihanda da koruyacağı ve gözeteceği anlaşılmaktadır.

Abdülkadir Geylânî (ö.561/1166), ölümü hatırdan çıkarmamayı, sıkıntılara sabretmeyi, bütün hallerde mütevekkil olmayı tavsiye etmiş ve şu açıklamalarda bulunmuştur: "Ölümü hatırlamak, dünyaya rağbeti söndürür. Sabrederek, Rabbinden istediğin şeylere ulaşırsın. Tevekkül ile de her şey kalbinden çıkar ve Rabbine bağlanırsın. Dünya, ahiret ve Allah dışında her şey senden uzaklaşır. Her bakımdan huzura erer ve her yönden himaye edilirsin. Allah seni her şeyden korur ve kimse sana yaklaşamaz (zarar veremez)."99 Tevekkül sayesinde, kalbin saflaştığı, mâsivâdan uzaklaşıldığı, huzur ve sükûna kavuşulduğu ve Allah'ın koruması altına girildiği görülmektedir.

Hz. Peygamber, İbn Abbas'a şu tavsiyede bulunmuştur: "Bir şeyi istediğinde Allah'tan iste. Yardım istediğinde de Allah'tan iste. lyi bil ki; eğer bütün varlıklar gayret etseler de Allah'ın takdir etmediği bir konuda sana ne fayda ne de zarar veremezler. Çünkü bu konuda defter dürülmüş ve kalem kurumuştur."100 Kim, Allah'ın bilgisindeki bu taksimi müşahede ederse, bütün rızk endişeleri üzerinden kalkar, halkın elindekine bakmaktan kurtulur ve rahat eder. ${ }^{101}$ burada zikredilen hadis, "De ki: Allah bana bir zarar vermek isterse, Allah'ı bırakıp da taptıklarınız, O'nun verdiği zararı giderebilir mi? Yahut Allah bana bir rahmet dilerse, onlar O'nun bu rahmetini önleyebilirler mi? ${ }^{102}$ ayetinin yorumu gibidir. Allah istemedikten sonra, halkın fayda ve zarar veremeyeceğini, yegâne fayda ve zarar verecek olan kişinin Allah olduğunu bilmek, doğru bir tevekkül anlayışına sahip olarak halka değil Hakk'a teveccüh etmeyi sağlar. Bu bilgiye sahip olmak (marifet), havf ve recâ sahibi olmaya da sebep olur. Bu anlayışta, yalnız Allah'tan korkmak ve yalnız O'ndan ümit etmek vardır.

Kur'an'da yer alan, "De ki: Bana Allah yeter."103 "Allah bize yeter, O ne güzel vekildir." 104 şeklinde tevekkül ifade eden dualar, Hz. Peygamber'in ve

99 Geylânî, Abdülkadir, el-Fethu'r-Rabbânî, el-Mektebetü'l-Asriyye, Beyrut 1433/2012, s. 31.

100 Tirmizî, Sıfatu'l-kıyame, 59; Ahmed b. Hanbel, Müsned, IV, 410; Heysemî, Nuruddin Ali b. Ebi Bekir, Mecmau'z-Zevaid, I-X, Beyrut 1982, VII,189.

101 Mekkî, II, age., s. 8.

102 Zümer, 39/38.

103 Zümer, 39/38. 
Uhut savaşı öncesinde ashabının yaptığı duadır. Bu dua, aynı zamanda diğer peygamberlerin de duasıdır. Hz. İbrahim de, ateşe atıldığında bu duayı yapmıştır. Allah Teâlâ'nın; "Ey ateş! İbrahim için serinlik ve esenlik ol!"105 emri üzerine ateş onu yakmamış ve herhangi bir zarar da vermemiştir.

Allah, tevekkül ederek kendisine güvenen ve sığınan kimseleri, $\mathrm{Hz}$. İbrahim'i hiç zarar görmeden ateşin içinden çıkardığı gibi selamete çıkarır ve onlara hiç ummadıkları yerden rızk verebilir. Hz. Peygamber, "Şayet siz, Allah'a hakkıyla tevekkül etseydiniz, sabahları açlıktan karınları çekilmiş olduğu halde yuvalarından çıkarak, akşamları karınları dolu olarak dönen kuşlara rızk verdiği gibi, Allah size de rızkınızı verirdi."106 diyerek tevekkülün kazanımına işaret etmiştir. Kuşların, rızkı, yuvalarında beklemeyip yuvalarından ayrılarak dışarıda aramaları ve rızk peşinde koşmaları, Hz. Peygamber'in, tevekkülün nasıl yapılması gerektiği hususundaki mesajıdır.

Tevekkülün kazanımlarından birisi de şeytanın şerrinden kurtulmaktır. "Gerçek şu ki: Iman edipte yalnız Rablerine tevekkül edenler üzerinde onun (şeytanın) bir hâkimiyeti yoktur. Onun hâkimiyeti, ancak kendisini dost edinenlere ve onu Allah'a ortak koşanlaradır."107 ayetinden anlaşılacağı üzere şeytan, tevekkül sahipleri üzerinde hâkimiyet kuramayacaktır. Tevekkül sahibi olmak, Allah'a yakın olmayı (kurb) sağlamaktadır. Şeytanın hâkimiyet alanı ancak bûd ehliyle sınılıdır. Şeytanın şerrinden korunmanın yolu, bûd sahasından uzaklaşarak tevekkülle kurb sahasına girmektedir.

Tevekkül, imanın ve tevhid inancının güçlenip kuvvetlenmesinin de yoludur. Allah'tan başkasına güvenmek ve yönelmek, insanın izzet ve şerefini yok eder. Fakat tevekkül ederek sadece Allah'a güvenmek ve O'ndan yardım istemek, başkasına mahkûm olmaktan kurtararak insan izzet ve şerefini korur. Tevekkül, azla yetinerek kanaat sahibi olmaya, azalan nimetlere veya artan musibetlere karşı tahammül gücünü artırarak da sabır sahibi olmaya sebep olur. 108

104 Âl-i İmrân, 3/173.

105 Enbiyâ, 21/69.

106 Tirmizî, Zühd, 33; ibn Mace, Zühd, 14.

107 Nahl, 16/99, 100.

108 Tevekkül konusunda bkz. Kara, Mustafa, Tasavvuf ve Tarikatlar Tarihi, Dergâh Yayınları, İstanbul 1998, s. 109; Eraydın, Selçuk, Tasavvuf ve Tarikatlar, Marmara Ün. IFAV. Yayınları, İstanbul 1997, s. 166; Yılmaz, H. Kâmil, Anahatlarıyla Tasavvuf ve Tarikatlar, Ensar Neşriyat, İstanbul 2000, s.172; Bardakçı, M. Necmettin, Sosyo-Kültürel Hayatta Tasavvuf, Isparta 2000, s. 82; Kayıklık, Hasan, Tasavvuf psikolojisi, Akçağ Yayınları,Ankara 2009, s. 155; Gökcan, M. Mansur, Temel Ahlâkî Prensipleriyle Tasavvuf, Harf Eğitim Yayıncılığı, Ankara 2017, s 146;.Gökcan, M. Mansur, "Kuşeyrî́nin el-Cevâhiru'l-mensûre İsimli Eseri Bağlamında Tasavvufî Görüşleri”, (Doktora Tezi, Çukurova Üniversitesi Sosyal Bilimler Enstitüsü, Adana 


\section{Sonuç}

Kur'an ve hadiste her Müslümanın mükellef olduğu bir fariza olarak yer alan tevekkül, tasavvufta da önemli bir makam olarak yer almaktadır. Tevekkül ve iman, et ve kemik gibi birbirini tamamlamaktadır. Tevekkül, imanın gereği ve sonucu olduğu gibi, imanın güçlenmesi de tevekkülün sonucudur.

Tevekkül, Allah'a güvenmeyi ve mutlak teslimiyeti gerektirir. Güvenmek, tanımakla doğru orantılıdır. Marifet arttıkça güven de artar. Peygamberlerin, en mütevekkil kimseler olmaları, Allah'ı en iyi tanıyan kimseler olmalarındandır. Bu durum, tevekkülün derecesinin marifet derecesi ile orantılı olduğunu göstermektedir.

Varlıkların gücü, kendilerinden değil Allah'tandır. Kendilerinde güç olduğu zannedilen varlıklar da Allah'a muhtaçtır. Tevekkül, muhtaç olan varlıklara değil, hiçbir şeye muhtaç olmayan Allah'a güvenmeyi ve dayanmayı öngörür.

Allah'ın kefaleti, sadece insanlarla sınırlı kalmayıp tüm varlıkları kapsar. Tevekkül, Allah'ın, bu kefaletine güvenerek rızk konusunda endişe duymamaya ve huzurlu bir hayat yaşamaya sebep olur.

Tevekkül, kalbîn işidir. Fakat kalp ile güvenmek bedenen çalışmaya engel değildir. Bu konuda en güzel örnek Hz. Peygamberdir. Tevekkül onun hali, çalışmak da onun sünnetidir. Kalben tevekkül halinde olan kimsenin, bedenen de çalışmayı terk etmemesi gerekir.

Tevekkül, halkın elindekine değil Hakk'ın elindekine güvenmeyi, halkın elindekinden ümit kesmeyi; halka değil, Hakk'a teveccüh etmeyi ve sadece O'ndan korkmayı icap ettirir. Bu durum da, tevekkülün, sağlam bir havf, recâ ve teveccüh anlayışına sahip olmayı gerektirdiğini gösterir.

Dünyaya karşı sabır, dünyanın hazlarına karşı sabır göstermektir. Tevekkül, dünyaya karşı sabır göstererek kalbin dünya ile alakasını kesmesine ve Allah'a bağlamasına vesile olmaktadır.

İyi zannedilen şeylerin sonu kötü, kötü zannedilen şeylerin sonu da iyi olabilir. Tevekkül, bütün işleri, her şeyin içyüzünü bilen ve kulu için en doğru kararı verecek olan Allah'a bırakarak en sağlam kulpa tutunmaya sebep olur.

Rızkın, fayda ve zararın, sadece Allah'tan geldiğine yakîn olarak inanarak tevekkül etmek, mâsivâya meyletmekten kurtararak Allah'a yönelmeye ve O'nun istediği gibi kulluk etmeye yol açar.

2015, s.139.); Erkaya, Mahmut Esad, Kur'an Kaynaklı Tasavvuf Kavramları, Otto Yayınevi, Ankara 2017, s. 107.

ÇÜIFD, 2018, cilt: 18, sayı: 1, ss. 131-165 
Tevekkül, başkasına güvenmemeyi gerektirdiği gibi, kendi gücüne ve çalışmasına da güvenmemeyi gerektirir. Allah'tan başkasında bir güç olduğuna inanmak şirke sebep olabilir. Doktor ve ilaç vasıta, şifa Allah'tandır.

Allah'a güvenmek anlamını taşıyan tevekkülü belirli bir zamana hasretmek, diğer zaman dilimlerinde güvenmemek anlamına gelebilir. Bu bakımdan tevekkül, işin başında da, ortasında da, sonunda da Allah'a güvenmeyi esas alır.

İmanın ve tevhid akidesinin güçlenmesine sebep olan tevekkül, şeytanın şerrinden ve dünyanın sıkıntılarından kurtulmanın da yoludur. Allah, kendisine güvenen kimseleri, Hz. İbrahim'i ateşin içinde yanmaktan kurtardığı gibi, hiç beklemediği yerlerden nimetler vererek sıkıntılardan kurtarır.

\section{Kaynakça}

Aclûnî, İsmâil b. Muhammed el-Cerrâhî, Keşfu'l-hafâ, I-II, Beyrût 1405.

Ahmed b. Hanbel, Müsned, thk. Şuayb el-Arnavût ve diğerleri, I-VIII, Müessesetü'r-risâle, Beyrut 2001.

Ahmed el-Âyid ve diğerleri, el-Mu'cemü'l-Arabiyyü'l-Esâsî, Mektebetü Lârûs, Alesco 1988.

Altuntaş, Halil, Muzaffer Şahin, Kur’an-ı Kerim Meâli, Diyanet İşleri Başkanlığı Yayınları, Ankara 2009.

Aydın, Mehmet, İslâm Dini İlmihali, Hibaş Yayınları, Konya 1981.

Bardakçı, M. Necmettin, Sosyo-Kültürel Hayatta Tasavvuf, Isparta 2000.

Beyhakî, Ebû Bekr Ahmed b. el-Huseyn, Şuabu'l-iman, I-VIII, Beyrut 1410.

Buhârî, Ebû Abdullah Muhammed b. İsmâil el-Cu'fî, Sahîhu'l-Buhârî, I-VII, Beyrût 1410/1990.

Ceylî, Abdülkerim, Insan-ı Kâmil, trc. Abdülkadir Akçiçek, Kurtuba yayınları, İstanbul 2016.

Ebû Dâvûd, Süleyman b. el-Eş'as es-Sicistânî, Sünenu Ebî Dâvûd, I-III, Beyrût 1409/1988.

Ebû Ya'lâ Ahmed b. Ali el-Musennâ, Müsned, I-VIII, Dımeşk 1984.

Eraydın, Selçuk, Tasavvuf ve Tarikatlar, Marmara Ün. IFFA. Yayınları, İstanbul 1997.

Erkaya, Mahmut Esad, Kur'an Kaynaklı Tasavvuf Kavramları, Otto Yayınevi, Ankara 2017. 
Erzurumlu İbrahim Hakkı, Mârifetnâme, sadeleştiren M. Fuat Başar, Âlem Tic. ve Yayıncılık, İstanbul ts.

Gazâlî, Ebû Hâmid Muhammed b. Muhammed, Ihyâu ulûmi'd-dîn, I-V, Müessesetü'l-Halebî, Kahire 1387/1967.

-------, Minhâcü'l-âbidîn, Müessesetü'r-risâle, Beyrut 1409/1989.

-------, Mükâşefetü'l-kulûb, Mektebetü Üsame b. Zeyd, Halep ts.

-------, Kimyâ-yı Saâdet, s. 525. Çev. Mehmed A. Müftüoğlu, İstanbul 1981.

Geylânî, Abdülkadir, el-Fethu'r-Rabbânî, el-Mektebetü'l-Asriyye, Beyrut 1433/2012.

Gökcan, M. Mansur, Temel Ahlâkî Prensipleriyle Tasavvuf, Harf Eğitim Yayıncılığı, Ankara 2017.

--------, “Kuşeyrî’nin el-Cevâhiru'l-mensûre Ísimli Eseri Bağlamında Tasavvufî Görüşleri”, (Doktora Tezi, Çukurova Üniversitesi Sosyal Bilimler Enstitüsü, 2015.)

Halil el-Curra, Lârûs, Mektebetü Lârûs, Paris 1973.

Herevî, Ebû İsmail Abdullah el-Ensârî, Menâzilü's-sâirîn, Dâru'l-kütübi'lilmiyye, Beyrut 1988.

Heysemî, Nuruddin Ali b. Ebi Bekir, Mecmau'z-Zevaid, I-X, Beyrut 1982.

Hucvirî, Ali b. Osman Cüllâbî, Keşfu'l-mahcûb, trc. İs'âd Abdülhâdî Gandil, Dâru'n-nehdetü'l-ğarbiyye, Beyrut 1980.

-------, Keşfu'l-mahcûb, çev. Süleyman Uludağ, Dergâh Yayınları, İstanbul 1996.

İbn Arabî, Muhyiddîn, el-Futuhâtu'l-Mekkiyye, Dâru'l-kütübi'l-ilmiyye, I-X, Beyrut 1460/1999.

İbn Hibbân, Ebû Hâtim Muhammed b. Ahmed el-Bustî, Sahîhu İbn Hibbân, IXVIII, Müessesetü'r-risâle, Beyrut 1998.

İbn Mâce, Sünenü İbn Mâce, I-V, Dâru'r-risâletü'l-âlemiyye, Beyrut 1430/2009.

İbn Manzûr, Ebû'l-Fadl Cemâluddin Muhammed b. Mükrim b. Ali el-Ensârî, Lisanu'l-Arab, I-VI. Dâru'l-maârif, Kahire 1979.

Kaplan, Hayri, İslam Düşünürlerine Göre Ruh ve Nefs (Yüksek Lisans Tezi, Ankara Üniversitesi Sosyal Bilimler Üniversitesi, 1995.)

Kara, Mustafa, Tasavvuf ve Tarikatlar Tarihi, Dergâh Yayınları, İstanbul 1998.

Kayıklık, Hasan, Tasavvuf psikolojisi, Akçağ Yayınları,Ankara 2009.

Kelâbâzî, Ebû Bekr Muhammed b. İshâk, et-Tarruf li-mezhebi ehli't-tasavvuf, thk. Ahmed Şemsüddin, Dâru'l-kütübi'l-ilmiyye, Beyrut 2011. 
Kuşeyrî, Ebû'l-Kâsım Abdülkerim b. Havâzin b. Neysâbûrî, er-Risâletü'lKuşeyrîyye, Dâru'l-hayr, Beyrut 1997.

--------, el-Cevâhiru'l-mensûre, thk. ve trc. M. Mansur Gökcan, Harf Yayınları, Ankara 2017.

Kübra, Necmüddin, Usûlu aşere, (Tasavvufî Hayat) Hazırlayan Mustafa Kara, Dergâh Yayınları, İstanbul 1996.

Mekkî, Ebû Talib, Kûtu'l-kulûb, I-II, Dâru sâdır, Kahire 1310/1892.

Muhâsibî, Ebû Abdullah Hâris b. Esed, er-Riaye li-hukûkillah, Dâru'l-kütübi'lilmiyye, Beyrut 2010.

-------, Risâletü'l-müsterşidin, Dâru'l-Beşâiri'l-İslâmiyye, Beyrut 2014.

Müslim, Ebu'l-Huseyn Müslim b. el-Haccâc el Kuşeyrî, Sahih, I-V, nşr. Muhammed Fuâd Abdülbâkî, Dâru İhyâi'l-Kütübi'l-Arabiyye, Kahire 1991.

Râgıb el-İsfahânî, Ebu'l-Kâsım Hüseyn b. Muhammed, el-Müfredât, Dâru'lkalem, Beyrut 1412/1991.

Schimmel, Annemaria, Tasavvufun Boyutları, Adam Yayınları, İstanbul 1982.

Serrâc, Ebû Nasr Abdullah b. Ali et-Tûsî, el-Lûma, Dâru'l-kütübi'l-ilmiyye, Beyrut 2001.

Sühreverdî, Ebû Hafs Şihabüddin Ömer b. Muhammed, Avârifü'l-meârif, I-II, thk. Abdülhalîm Mahmud, Muhammed İbn Şerîf, Dâru'l-maârif, Kahire ts.

-------, Makâmâtu's-sûfiyye, thk. Emile Maalouf, Dâru'l-meşrig, Beyrut 2002.

Sülemî, Ebû Abdurrahman Muhammed b. Hüseyin, el-Mukaddime fi't tasavvuf, Dâru'l-Cîl, Beyrut 1419/1999.

-------, Sülemî'nin Risaleleri, çev. Süleyman Ateş, Ankara Üniversitesi Basımevi, Ankara 1981.

Taberânî, Ebû'l-Kâsım Süleyman b. Ahmed b. Eyyûb, el-Mu'cemu'l-kebîr, IXXV, Mektebetü İbn Teymiyye, Kahire 1994.

Tilimsânî, Afîfüddin Süleyman b. Ali, Şerh'u menâzili's-sâirîn, I-II, Dâru't-Türkî, Tunus 1989.

Tirmizî, Ebû Îsâ Muhammed b. Îsâ b. Sûre, Sünenu't-Tirmizî, I-V, Beyrût ts.

Uludağ, Süleyman, Tasavvuf Terimleri Sözlüğü, Marifet yayınları, İstanbul 1991.

Yılmaz, H. Kâmil, Anahatlarıyla Tasavvuf ve Tarikatlar, Ensar Neşriyat, İstanbul 2000. 


\section{Understanding of Tawakkul in Sufism}

Citation / (C- Gökcan, M. (2018). Understanding of Tawakkul in Sufism, Çukurova University Journal of Faculty of Divinity, 18 (1), 131165.

Abstract- In Islamic nass, a faridah liable of every mu'min tawakkul takes place as an important station ('maqam') in sufism. In tawakkül defined as referring the work to somebody since he or she cannot perform or complete it, trust to Allah and submission are essential. Trustin and rely-on is proportionate to knowing a thing. As one's knowledge raises, his or her trust also increases. Likewise, the most trustful in Allah is the one having direct knowledge of Him the best. The reason of prophets being from them is because the individuals knowing Allah the most. This situation shows that the degree of tawakkul is based on the extent of knowledge. The existence of things is not on their own so is their power. Thinking that "the reason of light and heat is the sun" is the ignorance. All the existences are made available by Allah, and they can sustain their presence with the power that He bestows them. Who reaches this essence for sure recognizes that there is no power and will but Allah's, and trusts no creatures but in the Creator. One begs for help only from Him and tends only towards Him. Given that Allah stands a guarantor for the sustenance of creatures, he or she will not worry about it and and live in peace and serenity. As an indicator of believing in Allah, tawakkul represents the passionate and consent to indicate against things befallen, happiness with scarcity, and absolute trust and submission. This also calls for having sense of sound awe and raja. Who has fear of Lord inside will never afraid of nothing else. Allah will never leave him or her fearful and hopeful of Himself at another's hand. The ending of seemingly good things can be bad consequences and vice versa. Any secrets of inside and ahead of things only belongs to Allah, and therefore it is appropriate to trust in Allah, leave things to Him and consent with His Will. Relating to heart, tawakkul does not hinder the physical work. This does not mean simply to wholeheartedly trust in and just wait with doing nothing, but to make bodily labor and efforts in addition to relying on Allah. Tawakkul is the way of living a blessed life without worry of provision and maintaining honor and dignity as independent on others.

Keywords- Tawakkul, heart, belief, trust 